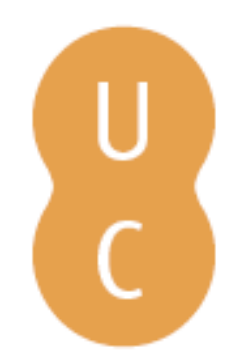

\title{
nommalina
}

\section{Harmonia e autonomia da aparência em Schiller: o transcendental revisitado}

Autor(es): $\quad$ Utteich, Luciano Carlos

Publicado por: Imprensa da Universidade de Coimbra

URL

persistente:

URI:http://hdl.handle.net/10316.2/38237

DOI:

DOI:http://dx.doi.org/10.14195/978-989-26-1049-8_3

Accessed : $\quad$ 26-Apr-2023 11:43:48

A navegação consulta e descarregamento dos títulos inseridos nas Bibliotecas Digitais UC Digitalis, UC Pombalina e UC Impactum, pressupõem a aceitação plena e sem reservas dos Termos e Condições de Uso destas Bibliotecas Digitais, disponíveis em https://digitalis.uc.pt/pt-pt/termos.

Conforme exposto nos referidos Termos e Condições de Uso, o descarregamento de títulos de acesso restrito requer uma licença válida de autorização devendo o utilizador aceder ao(s) documento(s) a partir de um endereço de IP da instituição detentora da supramencionada licença.

Ao utilizador é apenas permitido o descarregamento para uso pessoal, pelo que o emprego do(s) título(s) descarregado(s) para outro fim, designadamente comercial, carece de autorização do respetivo autor ou editor da obra.

Na medida em que todas as obras da UC Digitalis se encontram protegidas pelo Código do Direito de Autor e Direitos Conexos e demais legislação aplicável, toda a cópia, parcial ou total, deste documento, nos casos em que é legalmente admitida, deverá conter ou fazer-se acompanhar por este aviso. 

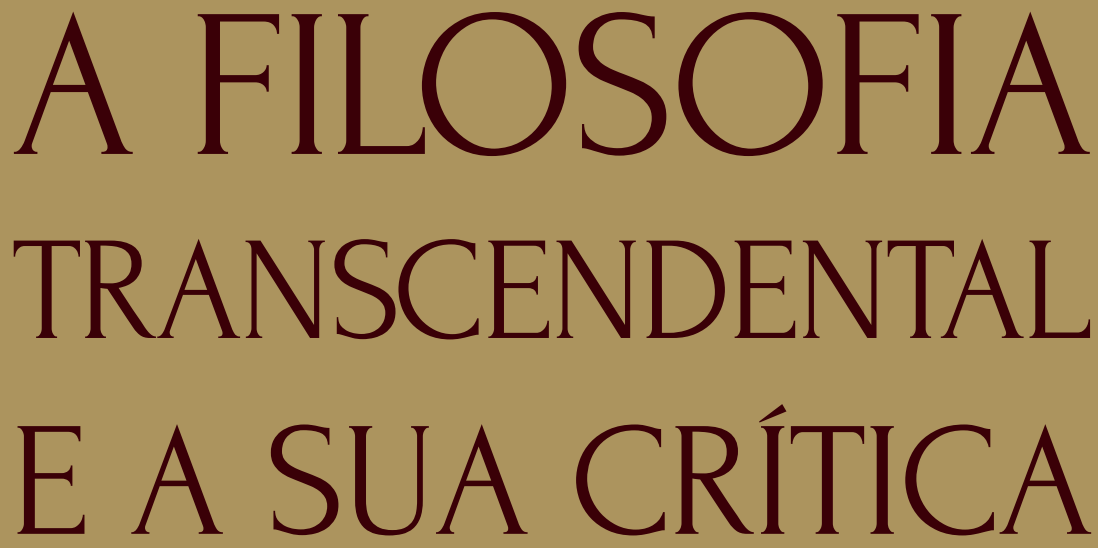

IDEALISMO • FenOMENOLOGIA • HERMENÊUTICA

\author{
DIOGO FERRER \\ LUCIANO UTTEICH \\ (COORDENADORES)
}




\title{
HARMONiA E AUtONOMIA DA APARÊNCIA EM SCHILlER: O TRANSCENDENTAL REVISITADO

\author{
HARMONY AND AUTONOMY IN SCHILLER:
} \\ THE TRANSCENDENTAL REVISITED
}

Luciano Carlos Utteich*

(UNIOESTE - Universidade Estadual do Oeste do Paraná, Brasil)

\begin{abstract}
In a note in Religion within the Limits of Reason Alone (1793), Kant comments Schiller's utterance, contained in On Grace and Dignity (1793), as having associated the aesthetic element (grace) to the purely moral element (dignity). However, such an approach is impracticable due to the dignity of the law. From other texts by Schiller, such as the fragment of the Lectures on Aesthetics (1792-3), On the Sublime (1793), On the Usefulness of Moral Customs Aesthetic (1793) and Letters on the Aesthetic Education of Man (1795) one can show that he does not thought the interaction between grace and
\end{abstract}

\footnotetext{
*lucautteich@terra.com.br

Pós-doutor pela Universität Duisburg-Essen (Alemanha) e doutor pela Pontifícia Universidade Católica do Rio Grande do Sul (PUC-RS). Professor Adjunto dos Cursos de Graduação e de Pós-Graduação (Stricto Sensu) em Filosofia da UNIOESTE - Campus Toledo. Dedica-se à investigação da Filosofia transcendental de Kant, dos primeiros pós-kantianos (Reinhold, Maimon, Schulze e Jacobi), do Idealismo alemão (Fichte, Schelling e Hegel) e dos românticos alemães (Schlegel, Novalis e Schiller). Coordenador do GT-Dialética (ANPOF) e do Grupo de Pesquisa "Filosofia, Ciência e Natureza na Alemanha do século XIX" (Unioeste). Membro da ALEF (Associação Latino-Americana de Estudos sobre Fichte) e da Red Iberoamericana de Estudios Schellinguianos.

Agradeço à CAPES pelo apoio.
} 
dignity in the form it was imputed him by Kant. Without attracting to itself the aesthetic element (grace), in Schiller's understanding the dignity does not reject it, in the face of it should not leave involve itself in the extremes of the human condition, to the savage and the barbarian. We demonstrate this by thematising the notions of allocation and disinterested affection.

Keywords: Transcendental philosophy; Faculty of aesthetic judgment; Moral law; Duty; Taste

Resumo: Em nota a A Religião nos Limites da Simples Razão (1793), Kant comenta a exposição de Schiller, em Graça e Dignidade (1793), como tendo associado o elemento estético (graça) ao elemento puramente moral (dignidade) sendo, porém, tal aproximação indevida em face da dignidade da lei. A partir dos demais textos de Schiller, como o Fragmento das Preleções sobre Estética (1792-3), Do Sublime (1793), Sobre a Utilidade Moral de Costumes Estéticos (1793) e as Cartas sobre a Educação Estética do Homem (1795), pode-se mostrar que este não pensou a interação entre graça e dignidade no modo como lhe imputara Kant. Sem atrair para si o elemento estético, na compreensão schilleriana a dignidade antes não o rejeita, em face de não dever se deixar associar aos extremos da condição humana, a do selvagem e a do bárbaro. Isso pode ser demonstrado tematizando-se as noções de destinação e afeto desinteressado.

Palavras-chave: Filosofia transcendental; Faculdade de juízo estético; Lei moral; Dever; Gosto

Na elaboração de sua teoria estética Schiller enunciou a influência recebida da teoria estética kantiana, em complemento da qual visara estabelecer "[...] objetivamente o conceito de beleza e legitimá-lo 
inteiramente a priori pela razão [...]"162. Se neste domínio ele foi além da fundação meramente subjetiva da experiência estética, estabelecida por Kant na Crítica da Faculdade do Juízo (1790) ${ }^{163}$, em sua demarcação teórica ele se opôs de modo ainda mais estrito a Kant em relação à doutrina dos costumes e à interpretação rigorista do imperativo categórico, expostos na Fundamentação da Metafísica dos Costumes (1785) e na Crítica da Razão Prática (1788). Nas correspondências com o Príncipe de Augustenburg (1793), a primeira versão teórica de Sobre a Educação Estética numa Série de Cartas ${ }^{164}$, e em Sobre Graça e Dignidade (Über Anmuth und Würde, 1793), Schiller perpassou pela sua Teoria Estética madura a exigência rigorista da moral kantiana ao mostrar que as ideias estéticas e morais (contemporaneamente subentendidas como valores ${ }^{165}$ ), se por um lado não nascem juntas, por outro só se deixam mostrar em conjunto. Tais ideias, a fim de serem apresentadas, exigem ser mantidas juntas e seguidas pelo séquito das demais faculdades que, para se mostrarem ativas, requerem ser pensadas como não deixadas

162 Schiller (2002), 41; (2010), 5. As citações se referirão por primeiro ao texto publicado em português e, nos casos respectivos, em seguida à paginação da edição alemã.

163 Kant desenvolveu a fundamentação exclusivamente transcendental dos juízos estéticos. Neste sentido ele não tematizou uma abordagem do vínculo entre fundamentação e aplicação, denominado por nós autorreflexividade. Para uma abordagem sobre as diferenças na fundamentação da experiência estética em Kant e Schiller, Cf. HAMM, Christian (2009): Experiência estética em Kant e Schiller. In: WERLE, M. A.; GALÉ, P. F. (org.). Arte e Filosofia no Idealismo Alemão. São Paulo: Barcarolla, pp. 53-75.

$164 \mathrm{O}$ texto Über die ästhetische Erziehung des Menschen in einer Reihe von Briefen recebeu no Brasil duas traduções. A primeira de Anatol Rosenfeld (Cartas sobre a Educação Estética da Humanidade), publicada pela Editora Herder (São Paulo, 1963), e a segunda de Roberto Schwarz e Márcio Suzuki ( $A$ Educação Estética do Homem), pela Iluminuras (São Paulo, 1995). Mencionaremos nas citações do corpo do texto a paginação do texto da edição brasileira de 1995 e em nota de rodapé a página no original, editado pela Reclam-Verlag. E para as obras de Kant, no corpo do texto a numeração de página da edição portuguesa da Calouste-Gulbenkian e em nota de rodapé a numeração da edição alemã da Academia.

165 Kant definiu a faculdade da imaginação transcendental (Einbildungskraft) como "[...] fonte das ideias estéticas [...]" Kant (1995), 106; (1968), 101. Enquanto resulta de um contexto de equilíbrio no convívio social, se passou a considerar contemporaneamente a autonomia da aparência e das ideias estéticas como constituindo esferas de valores autônomos. Para uma abordagem desenvolvida nesta perspectiva, Cf. Habermas (2000), 71. 
isentas de tarefas. Aqui a perspectiva do pensamento transcendental é tematizada desde uma dimensão ampliada: as concepções de gosto, de beleza e arte são ampliadas no seu uso até um domínio relativamente diferenciado, tratadas visando a sua aplicação na formação moral e estética dos afetos e da sensibilidade. Como elemento diferencial sobrevém o acréscimo do momento da aplicação dos conceitos estéticos, para além do da fundação, como consentâneo a este ${ }^{166}$. Este elemento

166 Ao associar o momento da aplicação como consentâneo ao da fundação, Schiller excedeu a perspectiva transcendental fundada em Kant. Hegel enfatizou ter Schiller descoberto "[...] na ideia do belo artístico, da unidade concreta do pensamento e da representação sensível [...]" o modo de escapar das abstrações do entendimento separador. Segundo ele, "[...] a produção artística, a individualidade viva, é de certo modo limitada em seu conteúdo; [...] [mas] a ideia - [que é] abrangente também segundo o seu conteúdo [...]", não podia ter sido colocada, como o fez Kant, "[...] dentro da harmonia [só] postulada da natureza ou necessidade, com a finalidade da liberdade, no fim último [sumo Bem], pensado como realizado [...]" (Hegel (1995), 131), visto que através disso fora jogado para fora dos limites da razão pura a unificação entre natureza e razão. Pela descoberta da "unidade concreta" na ideia do belo artístico, Schiller trouxe a atividade que é ao mesmo tempo síntese transcendental iniciada pela faculdade reflexiva estética, explicitada de modo fluente por Hegel na ênfase de que "[...] a presença e a existência dos organismos vivos e do belo artístico já mostra a efetividade do ideal também para o sentido e para a intuição [...]" (Hegel (1995), 131-2), por meio do qual aparecem conjugados o ato da reflexão e a objetividade do pensado pela razão na relação com a natureza. Por sua vez, na questão da fundamentação pura do juízo de gosto desenvolvida por Kant na Crítica da Faculdade do Juízo, concernente à legítima pretensão à normatividade trazida pelo juízo de gosto puro, observa Allison (Allison (1998), 83-99) como tendo de permanecer, invariavelmente, insuficiente a justificação de qualquer pretensão particular do gosto (Cf. Allison (1998), 96), pelo fato de isso ser conforme à coerência da perspectiva transcendental do método fundado por Kant. Como examina Allison, ainda que o quid juris e o quid facti são exigidos conjuntamente pela análise kantiana para legitimar o juízo de gosto, o resultado da análise implica como nunca devendo poder ser alcançada a certeza sobre se, relativo ao quid facti, foi subsumido "[...] corretamente o objeto dado a essas condições [...]" (Kant (1995), 137; (1968), 152), que foram previamente pressupostas pela quid juris do juízo de gosto, a saber, aquelas condições segundo as quais é evidenciado, nas palavras de Kant, que "[...] o juízo tenha levado em consideração apenas essa relação [subjetiva das faculdades cognitivas] (e, por conseguinte, a condição formal da faculdade de julgar) e que seja puro, isto é, que não esteja mesclado nem a conceitos do objeto, nem a sensações como [sendo] as razões determinantes do juízo [reflexionante estético]" (Kant (1995), 136 nota; (1968), 152, Fussnote), uma vez que o juízo de gosto se baseia no sentimento (prazer da reflexão), e não em conceitos. Ocupada exclusivamente com a fundação das condições de possibilidade no sujeito, a perspectiva do método transcendental em Kant assenta um caráter de indeterminação e abertura, já que carece se legitimar apenas como iniciando a abordagem dos objetos pensados necessariamente pela razão mediante condições subjetivas, permanecendo vinculado a objetos sem atrelá-los ao mesmo 
adicional perfaz uma volta completa da reflexão e atende ao uso do ponto de vista sistemático e fundamental ${ }^{167}$, da faculdade de ajuizamento estético (Gosto), visando à aplicação dos conceitos estéticos. Nos demais textos do período ${ }^{168}$ Schiller manteve sua exposição assentada nesse enfoque e questionou o fato de a perspectiva transcendental em Kant ter se habituado “[...] a pensar o material meramente como um empecilho e a sensibilidade numa contradição necessária com a razão"169. A Kant se tornara imprescindível considerar a razão descolada dos aspectos contingentes da matéria, em cuja perspectiva vira não só como possível, senão antes como “[...] decisivo libertar a forma do conteúdo e manter o necessário puro do contingente [...]"170, por entender a sensibilidade como obstruindo o caminho nas operações

tempo sistematicamente na razão, por não poder admitir como instância autônoma a fornecida pela representação estética da finalidade (finalidade formal), para organon na Crítica da Faculdade de Juízo.

167 Ao enfatizar na Grundlegung zur Metaphysik der Sitten que “[...] a utilidade ou a inutilidade nada podem acrescentar, ou tirar valor" à boa-vontade, visto a utilidade apenas representar "[...] o engaste para essa joia [a boa vontade] poder ser manejada mais facilmente na circulação corrente, ou para atrair sobre ela a atenção daqueles que não são ainda bastante conhecedores, mas não para recomendá-la aos conhecedores e determinar o seu valor [...]" (Kant (1997), 23; (1968), BA 4), Kant pontua a função nuclear da boa-vontade no desenvolvimento do conceito de dever e da moralidade, já que ela permanece "[...] brilhando por si mesma como uma joia, como alguma coisa que em si mesma tem o seu pleno valor [...]." Nesta medida, representa a dignidade (Würde) e não pode ser associada a elementos da sensibilidade. Por sua vez, conforme Schiller expôs na introdução à Sobre Graça e Dignidade mediante a alegoria da deusa da beleza cujo cinturão mágico transmite graça (Anmut) àquele que o porta, a graça é "[...] beleza em movimento [...]" que se origina e também cessa casualmente no sujeito. Distinguindo-se da beleza fixa como necessariamente dada ao sujeito, o elemento estético (graça) é priorizado pela faculdade do Gosto como aquele elemento de utilidade, nos moldes do expresso acima por Kant, como auxiliando a pôr em circulação o elemento moral. Ao se pressupor o Gosto como aplicado à formação moral e estética dos afetos e da sensibilidade exige-se, portanto, entender o domínio da moral e do dever não só como intrinsecamente preservados, senão como comportando uma transitividade entre si mediante a dinâmica da faculdade estética. Schiller (2008), 10; (2010), 69.

168 Trata-se dos textos: Do Sublime (1793), os Fragmentos das Preleções sobre Estética (1792-1793), o Sobre a Utilidade Moral dos Costumes Estéticos (1793) e as Cartas sobre a Educação Estética da Humanidade (1795).

169 Schiller (1995), 72 nota); (2010), 51, Fussnote.

170 Schiller (1995), 72; (2010), 51. 
da razão. Assim grassara na letra kantiana o predomínio da forma do puro conhecer do entendimento (Verstand) e da ação pura prática da razão (Vernunft), em vista de pressupor a natureza (Natur) como exclusivamente oposta à razão, e não também como vindo ao seu encontro. Ao demonstrar que os conceitos estéticos estão vinculados à compreensão de uma função concreta a ser desempenhada, Schiller anuncia esse momento da aplicação como autorreflexão, isto é, movimento da reflexão condicionado estruturalmente no modo de representar os objetos visando a pensá-los do ponto de vista não-determinante. Esse modo de representação é constituído pelo Gosto, que considera a aplicação dos conceitos na perspectiva de seu lugar sistemático. Para isso Schiller enfatizou a noção de representação (Vorstellung) desenvolvida enquanto aparência estética (ästhetischer Schein), admitindo um novo tônus à atividade das faculdades transcendentais do sujeito, através do qual se desenvolve a ideia da natureza em harmonia com a razão (Vernunft). Por estender o estatuto transcendental também à simples aparência (Schein), torna-se possível compreender a dimensão autônoma da aparência estética, mediante a qual a natureza (Natur) passa a ser concebida não mais de modo unilateral e exclusivamente hostil ao ideal de humanidade. No opúsculo Sobre Graça e Dignidade (1793) ${ }^{171}$ Schiller expôs o modo de atuar conjunto dos elementos morais e estéticos mediados pelo Gosto, numa interação sistemático-estrutural a favor da compatibilização entre a perspectiva da beleza ("liberdade no fenômeno" 172 ) e a da liberdade moral. Mas conservou ao mesmo tempo as esferas da estética e da moral em domínios específicos, como não se imiscuindo nem interferindo no domínio contíguo. No texto A Religião nos Limites da Simples Razão (1793), Kant objetou a Schiller ter executado

171 Schiller menciona em carta de 13 de julho 1793, enviada ao príncipe de Augustenburg, o envio anexo do pequeno texto intitulado Sobre Graça e Dignidade, publicado no mês anterior na revista Neue Thalia. Schiller (2009), 84; (2010), 144.

172 Schiller (2002), 60; (2010), 24. No texto Schiller definiu a beleza dizendo: “A beleza não é pois outra coisa senão liberdade no fenômeno." 
uma associação indevida dos elementos morais e estéticos, em Sobre Graça e Dignidade, e de ter vinculado o elemento moral (dignidade) ao estético (graça), condicionando o moral como atraído pelo estético, unificando num único domínio esferas inconciliáveis e ferido assim a dignidade da lei pura prática da razão.

Visando elaborar um estudo da recensão que Kant faz, em nota de rodapé n'A Religião nos Limites da Simples Razão (1793), serão contextualizadas aqui as noções de graça e dignidade na abordagem schilleriana enquanto elementos formadores vinculados à aplicação dos juízos estéticos. Para tanto será enfatizada a concepção harmônica de natureza e razão na explicitação do critério transcendental como subsumindo a noção de aparência estética (ästhetischer Schein), em vista da qual aparecem unificadas determinações oriundas da Crítica da Razão Pura e da Crítica da Faculdade do Juízo, como momentos prévios à exposição de uma doutrina Estética transcendental em geral. Do lado da Crítica da Razão Pura desenvolverei o primeiro dos dois lados da unificação dos resultados da Estética transcendental, pela distinção do fenômeno em sentido geral como aparecimento (fenômeno) no sentido lógico (Erscheinung) e como mero aparecer (Schein), antecipando a exigência de legitimar uma doutrina estética do simples aparecer (Schein) como aparecer estético (ästhetischer Schein), desenvolvida por Schiller. Em seguida, do lado da Crítica da Faculdade de Juízo desenvolverei o segundo lado do pressuposto sistematizador da doutrina da Estética pela tematização da noção de natureza (Natur) do ponto de vista formal-reflexivo na terceira Crítica kantiana, vinculada aos aspectos formais da faculdade do juízo reflexiva e, por isso, também da liberdade (prática). Devido à atividade de colocar em relação as dimensões prática (liberdade) e teórica (natureza) da razão, a faculdade mediadora do juízo reflexivo fora evidenciada na Crítica da Faculdade do Juízo (Kritik der Urteilskraft) de Kant como assentada na autonomia do sujeito (Gosto). Evidencia-se, assim, que as condições de todo aparecer estético bem como de toda dimensão fenomênica têm de 


\title{
ser submetidas ao sujeito, em conformidade ao ponto de vista crítico
} exigido pela faculdade de ajuizamento reflexivo-estético (Gosto). ${ }^{173}$

\author{
A fim de iniciar uma resposta à objeção de Kant, tematizarei o tipo \\ de legitimidade alcançada pelo Gosto em sua autonomia pelas noções
}

173 O estofo da liberdade da faculdade de juízo reflexiva aparece em contraste com o pressuposto da liberdade prática, extraindo daí o distanciamento relativo aos domínios da liberdade prática e da natureza e, ao mesmo tempo, a possibilidade de estabelecer a relação mediada entre eles, na conservação de sua autonomia. Tal primazia do Gosto (faculdade de ajuizamento estético) assenta, segundo Kant, na precedência da dimensão estética da faculdade do juízo reflexiva (Kant (1995), 33; (1968), XLIII), como parte essencial da crítica da faculdade de julgar, face à dimensão teleológica, e consiste em que a ela é "[...] suficiente ser incluída na crítica do sujeito que julga e na crítica das faculdades de conhecimento do mesmo" (Kant (1995), 38; (1968), LIII). Enquanto funda a crítica subjetiva da faculdade do juízo e a parte da crítica das faculdades subjetivas do conhecimento, a dimensão estética da faculdade de juízo reflexiva (assentada na representação estética da finalidade (Zweckmässigkeit) como finalidade formal) se torna em propedêutica à Filosofia. À revelia da pressuposição exclusivamente crítica (canon) da faculdade de julgar reflexiva pode-se problematizar esse caráter propedêutico considerando-se que "[...] a respeito daquilo o que as faculdades podem realizar $a$ priori, uma crítica delas não possui na verdade qualquer domínio relativo a objetos" (Kant (1995), 20; (1968), XX). É indiscutível que a menos que se inicie pelo conceito de finalidade formal (faculdade de juízo estética) não se progredirá até a constituição do sistema da natureza, pensada como organizada. Em função disso, a faculdade de juízo reflexiva estética tem de ser considerada também organon da Crítica da Faculdade de Juízo, por estar intrinsecamente vinculada aos elementos constitutivos do aspecto sistemático da natureza. No escrutínio do que pode ser realizado pelo uso reflexionante do juízo segundo uma legislação própria, pelo fato de tal legislação "[...] conter princípios que por si não são úteis, nem para o uso teórico, nem para o uso prático" (Kant (1995), 21; (1968), XXI), se segue que a faculdade de juízo reflexiva tem princípios que são úteis unicamente para si mesma. E enquanto tal, a faculdade reflexiva do juízo tem de iniciar pela dimensão estética (conceito de finalidade formal) como dimensão só através da qual é possível se constituir um sistema. Segundo Kant, pela faculdade do juízo estético se entende a faculdade de ajuizar a finalidade formal (subjetiva) mediante o sentimento de prazer ou desprazer, em que "a consciência da conformidade a fins meramente formal no jogo das faculdades de conhecimento do sujeito em uma representação, pela qual um objeto é dado, é o próprio prazer [...]" (Kant (1995), 68; $(1968), 37)$ que, enquanto tal, liga-se "apenas ao sujeito; e o prazer [...] exprime a adequação desse objeto às faculdades de conhecimento que estão em jogo na faculdade de juízo reflexiva" (Kant (1995), 33-3; (1968), XLIV). Com efeito, deve ficar a critério da faculdade do juízo estética "[...] constituir a adequação desse produto (da sua forma) [segundo um princípio da conformidade a fins e não antes segundo leis da natureza universais] às nossas faculdades de conhecimento", ou seja, diz Kant, "[...] no gosto", enquanto a representação mesma de uma conformidade a fins (finalidade) da natureza é iniciada pelo princípio transcendental "[...] na relação subjetiva às nossas faculdades de conhecimento na forma de uma coisa" (Kant (1995), 37-8; (1968), LI) que, porque é o princípio de ajuizamento da forma da coisa, só pode permanecer indeterminado em quais casos tal ajuizamento tem de ser empregado. 
de destinação e afeto desinteressado, presentes no opúsculo de Schiller Sobre Graça e Dignidade. A inserção do aspecto formador (aplicação) do Gosto se realiza aqui como atividade harmônica que coloca os afetos e a sensibilidade sob a influência da cultura moral, numa paridade do Gosto com a Moral e com a Religião. E concluirei com a resposta à recensão de Kant, exposta na referida nota de rodapé n'A Religião nos Limites da Simples Razão (1793), reiterando a importância do aspecto formador do Gosto como fundamento subjetivo e condição para a instituição do código de leis objetivas (às leis da arte), fundadas como leis originárias do espírito que perfazem a cultura estética.

\section{Estética transcendental em amplitude sistemática: doutrina do fenômeno (Erscheinung) e do aparecer (Schein)}

Interessa a coerência sistemática na obra kantiana mediante a qual o estatuto transcendental da razão é desenvolvido em toda a sua envergadura crítica. É inquestionável a legitimidade da configuração espácio-temporal dos objetos de conhecimento, demonstrada na doutrina da Sensibilidade da Estética transcendental da Crítica da Razão Pura, que expôs as condições a priori subjetivas de compreensão da realidade dos objetos no espaço, enquanto exterior apenas à nossa representação, e não em si mesma. Nas conclusões do capítulo da Estética, Kant explicitou o critério, elevado a estatuto transcendental (chamado de distinção transcendental), para distinguir fenômeno e coisa-em-si, evitando com isso mantê-los atrelados a uma distinção meramente empírica, de um conhecimento como representando um objeto em si mesmo e de um outro, um objeto apenas como fenômeno. ${ }^{174}$ Pois,

174 Kant (1997), 80; (1968), B 62. Como enfatiza Kant, “[...] é-nos completamente desconhecida a natureza dos objetos em si mesmos e independentemente de toda esta receptividade da nossa sensibilidade. Conhecemos somente o nosso modo de os perceber, modo que nos é peculiar [...] [e é] o de todos os homens. É deste modo apenas que nos temos de ocupar" (Kant (1997), 79; (1968), B 59). 
disse Kant, caso "[...] pudéssemos elevar esta nossa intuição [como forma pura da sensibilidade] ao mais alto grau de clareza, nem por isso nos aproximaríamos mais da natureza dos objetos em si"175. Com efeito, isto assenta em que, complementa Kant,

“[...] toda a nossa intuição [sensível] nada mais é do que a representação do fenômeno; que as coisas que intuímos não são em si mesmas tal com as intuímos, nem as suas relações são em si mesmas constituídas como nos aparecem."176

Portanto, o espaço e o tempo desapareceriam, se "[...] fizermos abstração do nosso sujeito ou mesmo apenas da constituição subjetiva dos sentidos em geral", vindo a desaparecer com eles "[...] toda a maneira de ser, todas as relações dos objetos no espaço e no tempo", visto que os objetos "[...] como fenômenos (Erscheinungen), não podem existir em si, mas unicamente em nós"177.

As formas puras espaço-temporais, enquanto formas do nosso modo de perceber os objetos através de relações estabelecidas no vínculo da forma de nossas representações com as sensações (matéria das representações) referidas a objetos, torna patente que espaço e tempo são conhecidos "[...] antes de qualquer percepção real [...]", isto é, a priori, enquanto condições de possibilidade de sermos afetados por objetos

175 Kant (1997), 79; (1968), B 60. Percebe-se aqui a crítica ao tratamento leibniziano que, por atribuir clareza à forma do conhecimento, implicava encontrar clareza na matéria ou conteúdo do conhecimento (Cf. Leibniz (2004), 172-78). Kant é mais explícito na sequência na qual afirma: "A diferença entre uma representação clara e uma representação obscura é apenas lógica e não se refere ao conteúdo" (Kant (1997), 79; (1968), B 61). Daí porque "[...] a teoria, segundo a qual toda a nossa sensibilidade seria apenas a confusa representação das coisas, contendo simplesmente o que elas são em si mesmas, embora numa acumulação de características e representações parciais, que não discriminamos conscientemente, representa um falseamento dos conceitos de sensibilidade e de fenômeno, pelo que [ela] é vã e inútil”.

\footnotetext{
176 Kant (1997), 78-9; (1968), B 59.

177 Kant (1997), 78-9; (1968), B 59.
} 
(Gegenstanden). Daí que, “[...] seja qual for a espécie das nossas sensações, que podem ser muito diversas [...]", 178 as formas espácio-temporais são necessariamente inerentes à nossa sensibilidade. Esta elucidação preliminar é pertinente uma vez que por meio de tal distinção se torna útil confrontar, no estofo das falsas convicções dos modos idealista (Berkeley) e cético (Descartes) ${ }^{179}$, os modos equivocados de considerar o objeto (Gegenstand) tomado como coisa-em-si (Ding an sich). A utilidade deste confronto reside em considerar a distinção transcendental exposta acima como legitimadora tanto de uma estética do fenômeno (Erscheinung) ${ }^{180}$ como de uma estética do aparecer (Schein), guardadas

178 Kant (1997), 79; (1968), B 60.

${ }^{179}$ Nas concepções de um idealismo dogmático (místico ou fantasista), atribuído a Berkeley, e de um idealismo material (problemático ou sonhador), atribuído a Descartes - este último porque nega a possibilidade da prova e demonstração da existência de coisas exteriores à consciência, e o primeiro na medida em que considera o espaço como uma propriedade a ser atribuída às coisas em si -, no capítulo da "Refutação do Idealismo" (Kant (1997), 243; (1968), B 274-275), na Crítica da Razão Pura, Kant aplica os argumentos apresentados na Estética Transcendental, assinalando neles os limites de cada uma dessas abordagens, que não acompanham a elucidação crítica da noção de espaço como forma pura da intuição, apresentada como condição subjetiva na Estética Transcendental. Para uma tematização da distinção entre realismo transcendental e idealismo transcendental, cf. Allison (1992), 45-73.

180 No início da Dialética Transcendental na Crítica da Razão Pura, Kant caracteriza como fonte de erros e ilusões as falsas aparências lógicas (logischer Schein), como sofismas oriundos da desatenção em relação às regras lógicas do raciocínio, contudo, mostrados ali como capazes de serem corrigidos a fim de não perturbarem a razão. Do mesmo modo, identificou o que chama de ilusão ou aparência transcendental (transzendentaler Schein), como uma espécie particular de ilusão, já que é inevitável e subsiste podendo ser causa de erro e de engano, mesmo após descoberta sua origem. Como tarefa da razão, coube descobrir a causa dessas ilusões e enganos na própria razão, que a induziam a fazer um uso das categorias para além de toda a experiência, experiência esta que não pode fornecer um critério da correção deste uso, como atestação dos princípios utilizados pela razão. No fundo, o uso dos princípios pela razão induz a pensar num alargamento do conhecimento, partindo do sensível até o supra-sensível, enquanto miragem de uma extensão legitima a ser alcançada, constitutivamente, pela razão. Todavia, as ideias da razão têm de ser consideradas por estarem só fundando princípios reguladores do uso sistemático do entendimento no campo da experiência (Kant (1997), 534; (1968), B 672). Ao caracterizar a faculdade da razão como sede da aparência transcendental (Vernunft als dem Sitze des transcendentalen Scheins) (Kant (1997), 298; (1968), B 355), Kant leva a se tomar consciência de que as ideias da razão são ilusões (ou mais propriamente, ficções) e suas criações. Mas, com o fito de se aprender a viver com elas, por serem naturais e necessárias ao trabalho da 
pelo modo crítico-transcendental de considerar os objetos. ${ }^{181}$ Não é somente porque a função da Sensibilidade foi enfatizada na constituição do conhecimento teórico, na qual as formas puras espácio-temporais são elementos constitutivos, que essas formas deixam de se fundar de um ponto de vista válido ao mesmo tempo real e idealmente. Na abordagem tradicional (metafísica tradicional), espaço e tempo eram tomados como imediatamente acoplados aos objetos de conhecimento, tomados por isso já como coisas-em-si mesmas: os elementos espácio-temporais vinham presentes, por assim dizer, juntos com ou nos objetos. Por sua vez, com a abordagem crítico-transcendental de Kant, mostra-se que as formas espácio-temporais não podem trazer ou serem tomadas como possuindo um estatuto de realidade (objetividade) em si, tal como fora concedido tradicionalmente ao se admitir haver objetos como coisas-em-si mesmas. A exposição kantiana soluciona a questão pela distinção transcendental enquanto um critério estético, não empírico, elevado para estatuto transcendental: ao mostrar jungidas realidade

razão, importa não cair no erro de tomá-las por realidades (Realitäten) ou como lhes correspondendo objetos na natureza.

${ }^{181}$ Em contraste, observa Santos (Santos (2006): “Hans Vaihinger: o Kantismo como um Ficcionalismo?" In:__(Dir.): Kant: Posteridade e Actualidade. Lisboa: CFUL, pp. 515-536), Kant propiciou pensar pela faculdade de juízo estética uma outra dimensão da noção do fenômeno (Erscheinung), a saber, a motivada pelo "[...] jogo ficcional [...]" no qual ele, além de resolver "[...] as principais antinomias identificadas por Kant na sua terceira Crítica: entre a pretensão de validade universal e objetiva do juízo estético e o seu caráter de sentimento meramente privado; entre o idealismo e o realismo da finalidade acerca da beleza da natureza; entre a consideração mecânica e a apreciação teleológica da natureza como um sistema organizado de fins [...]" (Santos (2006), 535), também joga na ambiguidade, mas como "[...] uma ambiguidade consciente dos seus pressupostos e dos seus limites [...]", ou seja, mediante o seu jogo, continua Leonel Ribeiro dos Santos, "[...] laborando embora com ficções, não é contudo um jogo no vazio: é um jogo criador, não por certo dos objetos mesmos [em si] das suas representações, mas [jogo] de representações elas mesmas pertinentes e com sentido, ainda que nenhum objeto em concreto lhes corresponda" (Cf. Santos (2006), 536). Isso fora ilustrado por Santos através da ilustração do mencionando Discurso de Arguição de Kant a uma Dissertação Acadêmica, apresentada na Universidade de Königsberg a 27 de fevereiro de 1777, em cuja consideração final, favorável à compreensão do aspecto positivo das ficções poéticas, Kant concluirá dizendo: "A imagem [Species] que engana [fallit] desagrada, a que ilude agrada ainda mais e deleita [illudit placet admodum]." Apud Santos, 2006, 533-4. Acerca da tradução alemã do texto em latim, cf. Santos (2006), 515-536. 
empírica e idealidade transcendental, nas noções de espaço e tempo, é enfatizado que elas têm seu componente ideal na demonstração de que são só formas assentadas no sujeito e condições subjetivas; e seu componente real, no fato de que a supressão das condições receptivas dos objetos, como condições sensíveis assentadas no sujeito, reintroduz o tratamento do objeto como coisa-em-si mesma. No modo adequado de considerar a matéria do conhecimento, o fenômeno (Erscheinung), que só pode ser "intuído" pela faculdade da sensibilidade, mostra-se, em virtude disso, como um objeto inicialmente constituído pela faculdade receptiva do sujeito, fundada de modo transcendental, e obtém realidade (objetividade) somente por se vincular a uma representação (Vorstellung) do sujeito (capacidade representativa sensível), e não a uma coisa-em-si, já que esta eliminaria de vez a possibilidade de afirmar o conhecimento como objetivo para nós, de acordo com as condições pelas quais nós somos afetados por objetos. Devido ao critério da distinção transcendental estética se pode extrair uma consequência de dupla nuance. De um lado, no caso de as formas espaço-temporais não serem consideradas como as únicas estruturas da sensibilidade humana, vinculadas ao modo como os objetos aparecem (erscheinen) a nós e à nossa capacidade de representá-los, torna-se impossível justificar a realidade empírica e a idealidade transcendental destas estruturas e, nesta medida, diz Kant, “[...] não se pode evitar que tudo se transforme em simples aparência (Schein)"182 e ilusão. Por outro lado, as formas espácio-temporais facultam pensar as representações empíricas como sustentadas por um critério transcendental e garantidas desde o princípio da idealidade de todas as nossas intuições sensíveis, a um só tempo. Enquanto - graças a isso - nos livramos de converter o que se deve "[...] considerar como fenômeno (Erscheinung)"183 em simples aparência (Schein), também se pode considerar o simples

182 Kant (1997), 85; (1968), B 70.

183 Kant (1997), 85; (1968), B 70. 
aparecer (Schein) como denotando uma referência e vínculo à faculdade transcendental da sensibilidade do sujeito, portanto, às formas puras espácio-temporais, em virtude da qual se garante a supressão do pressuposto de que as relações das coisas em si mesmas seriam constituídas como nos aparecem ${ }^{184}$, pelo fato de que aqui a simples aparência (Schein) alcança ser o fundo de um fenômeno (Erscheinung), e também ela - aparência enquanto "Schein" - pode valer unicamente por isso ainda como representação (Vorstellung) somente no sujeito ${ }^{185}$.

Se não fosse possível distinguir isso, criar-se-iam condições para potencializar recaídas nos modos dogmático e cético, de tomar o objeto como coisas-em-si mesmas (sem poder conservar com isso o estatuto transcendental da faculdade da sensibilidade), ou seja, isso seria assim tanto caso se abrisse mão do estatuto transcendental - que distingue fenômeno e coisa-em-si (sem o qual não se pode entender a validade do princípio da realidade empírica e idealidade transcendental do espaço e do tempo) -; quanto se não fossem conservados também como distintos, de um duplo ponto de vista: 1) o aparecer (Erscheinung) e a simples aparência (Schein) ${ }^{186}$, ambos vinculados a um

184 Como diz Kant: “[...] quer essas formas [de espaço e de tempo] sejam necessariamente inerentes às coisas em si mesmas, quer apenas à nossa intuição das coisas [...] esta realidade do espaço e do tempo deixa, de resto, intacta a certeza do conhecimento por experiência, e este [conhecimento] é para nós igualmente seguro [...]" (Kant (1997), 77; (1968), B 56).

185 A fim de extrair um sentido adicional à noção do fenômeno como mero aparecer (Schein), considera-se a legitimidade de uma estética do puro aparecer, atendendo ao fato de que, do ponto de vista estético, o domínio da representação (Vorstellung) permanece atrelado a um interesse exclusivamente subjetivo, e de modo algum direcionado à natureza. Segundo Schiller, "[...] é a própria natureza que eleva o homem da realidade à aparência [...]" (Schiller (1995), 135; (2010), 109). E complementa dizendo assentar isto no fato de que a aparência aqui é uma aparência "[...] estética, isto é, uma aparência que não quer passar por realidade e tampouco quer que esta a substitua" (Schiller (1995), 137; (2010), 112).

186 Admitir o simples aparecer (Schein) como vinculado exclusivamente ao sujeito significa levar em conta a dimensão meramente subjetiva da representação de objetos, como vinculada ao critério transcendental. Desde aqui se inicia a unificação sistemática dos pressupostos da doutrina Estética na Crítica da Razão Pura e na Crítica da Faculdade de Juízo. Na Crítica da Faculdade do Juízo Kant atribuiu uma natureza estética (ästhetische Beschaffenheit) ao elemento meramente estético de uma representação, dizendo: "Aquilo 
critério transcendental devido às condições pelas quais são dados os objetos na intuição espácio-temporal; e 2) a simples aparência (Schein) como instância equívoca de uma consideração inadequada do objeto, tomado como uma coisa-em-si, numa condição verdadeiramente refratária às formas (espácio-temporais) da sensibilidade humana. ${ }^{187}$ Kant apresentou na Crítica da Faculdade do Juizo como contingente (zufällig) a concordância, do ponto de vista reflexivo, "[...] do objeto (Gegenstand) com as faculdades do sujeito [...]"188. Porém, para isso ele pressupôs, como subjacente ao objeto, a condição de que este fosse encarado como representação (Vorstellung) à base do conceito

que na representação de um objeto é meramente subjetivo (bloss subjektiv), isto é, aquilo que constitui a sua relação com o sujeito e não com o objeto, é a natureza estética (die ästhetische Beschaffenheit) dessa representação" (Kant (1995), 32-3; (1968), XLII).

187 Contemporaneamente, Clément Rosset (1988) levantou o questionamento sobre a legitimidade do estatuto da distinção entre aparência e realidade, imediação (sensível) e mediação (pensamento). Rosset desenvolve a ideia de que teria grassado não só nas áreas da literatura e da psicanálise, mas em toda a metafísica filosófica, uma falsa distinção entre duas perspectivas: uma voltada ao imediato (à realidade e ao sensível) e outra à realidade do pensamento (suprassensível). A partir disso ele se esforça para desenvolver argumentos que testemunhem que tal distinção não seria senão um engodo e produto de reflexões teoricamente incongruentes, afastadas da realidade mesma (teria ele partido da pressuposição de uma realidade em si mesma?). Já nos seus argumentos iniciais, contudo, se pode detectar equívocos na interpretação de textos clássicos da filosofia, como por exemplo, na sua interpretação da distinção kantiana entre fenômeno e noumeno, da Crítica da Razão Pura. Rosset atribui à distinção kantiana uma ilusória e equivocada duplicação de mundos, motivada pela exploração ontológica das noções de fenômeno e noumeno. Todavia, fica evidente de antemão o equívoco relativo à sua intepretação pela ausência de uma leitura rente ao texto kantiano. Na Crítica da Razão Pura Kant explicitou que: "A divisão dos objetos em fenômeno e noumeno, e do mundo dos sentidos e mundo do entendimento, não pode ser aceita (em sentido positivo), embora os conceitos admitam, sem dúvida, a divisão em conceitos sensíveis e conceitos intelectuais" (Kant (1997), 279-1; (1968), B 311 (grifo nosso) ). Se a distinção kantiana tivesse estabelecido ontologicamente uma separação entre mundo sensível e mundo inteligível e constituído através disto dois mundos concretos e reais, a tese inicial de Rosset poderia ser nutrida: um destes mundos teria de ser considerado produto de uma necessidade metafísica e pura ilusão; entretanto, o que o texto kantiano faz é justamente desautorizar essa duplicação: Kant propôs apenas que nos fosse facultado "pensar" dois mundos como constituídos distintamente, mas distintos apenas do ponto de vista conceitual (e não ontológico). Decerto isso não interessaria ao autor de $O$ Real e seu Duplo. Mas, mais uma vez, a tentativa de passar, de modo imediato, do domínio conceitual ao ontológico configura, segundo Kant, uma transgressão categorial contra a qual todo leitor do texto kantiano tem de se precaver de não cometer.

188 Kant (1995), 34; (1968), XLV. 
de finalidade (Zweckmässigkeit). Visto que em face das faculdades de conhecimento em geral do sujeito importa primeiramente a forma estética dos objetos ou a referência da representação do objeto dirigida exclusivamente ao sujeito, pode-se compreender o motivo de Schiller ter conduzido sua exposição na consideração da simples aparência (Schein) como representação (Vorstellung) ao mesmo tempo do e no sujeito, legitimada por se apartar da aparência lógica (como componente necessário que na sua vinculação é expressão do fenômeno como "Erscheinung").

Tendo em vista que a concordância das faculdades humanas com o objeto traz a marca do componente contingente ${ }^{189}$, na consideração estética dos objetos permanece a representação tendo de ser vinculada apenas ao sujeito, podendo à representação puramente estética ser atribuída uma aparência estética (ästhetischer Schein), sem vinculação direta ou estrita à dimensão lógica do entendimento determinante. Enquanto fundo da superfície de um fenômeno (Erscheinung), a simples aparência (Schein), do ponto de vista estético-reflexivo, não se liga com a aparência lógica (logischer Schein) ou com uma representação que visa ser determinada pelas condições humanas de conhecimento, mas se

189 O elemento contingente da concordância relativa, pensada entre nossas faculdades e o objeto da representação reflexivo-estética, foi explicitado na Crítica da Faculdade de Juízo pela figura do como se ( $A l s o b$ ). Na terceira Crítica o recurso ao como se (Als ob) é fundado na dependência do estabelecido estatuto do Idealismo da conformidade a fins (Zweckmässigkeit). Sob a influência da abordagem da filosofia kantiana trazida por Friedrich Albert Lange, em sua História do Materialismo (Geschichte des Materialismus und Kritik seiner Bedeutung in der Gegenwart, 2. vols., 1866), Hans Vaihinger explorou o recurso do "como se" para elemento explicativo da filosofia kantiana ao desenvolver a Filosofia do 'como se' (1911) visando explicitar a teoria kantiana no seu todo, a partir de uma teoria geral das ficções da mente, como sistema das ficções teóricas, práticas e religiosas da humanidade. Mas na tarefa de demonstrar a relação do como se aos princípios e conceitos heurísticos no pensamento kantiano, segundo Leonel Ribeiro dos Santos, Vaihinger teria acabado por cair numa "[...] muito generosa noção de 'ficção' [...]" por ter ignorado o vínculo de Kant da figura do "como se" mais estritamente à faculdade de julgar reflexionante, tornando-se nisso "[...] incapaz de compreender mais profundamente o als ob kantiano e tudo aquilo que ele indica." Cf. Santos (2006), 533. Daí a exigência de uma tematização mais aprofundada da questão dos conceitos heurísticos na filosofia kantiana, desprovida do vínculo à figura do como se. Cf. Vaihinger (2011). 
conserva desde outra instância, como o ângulo do fundo puramente estético do aparecer (Schein) (que carrega consigo o aspecto contingente) do fenômeno (Erscheinung) (que traz o aspecto lógico-necessário do entendimento), sem ser submetida, como mera aparência estética (ästhetischer Schein), a uma aparência lógica, como tem de ser feito no caso de se considerar a representação como fenômeno (Erscheinung) para um conhecimento determinado.

A pertinência de se conceder um estatuto autônomo à estética do simples aparecer (Schein) reside nisto: na medida em que não tem a ver com o fundamento lógico do objeto (como representação que se refere ao objeto através do sujeito), a aparência estética se vincula, como condição, estritamente à "forma" dos objetos, atendendo à exposição desenvolvida na Crítica da Faculdade do Juizo, do fundamento puramente estético da representação, considerado mediante as formas puras da intuição, as formas espácio-temporais ${ }^{190}$. Com base na distinção entre forma lógica e forma estética dos objetos, decisiva para a estética do aparecer, a doutrina do Idealismo da conformidade a fins (Zweckmässigkeit), na Crítica da Faculdade do Juizo, subsidia fornecendo o fundamento para considerar as formas puras espácio-temporais do sujeito como condições da sensibilidade, ativadas pela faculdade do juízo reflexivo, na perspectiva de que o sujeito também tenha de ser afetado por objetos a fim de produzir representações ${ }^{191}$, ainda

190 Outro elemento permite considerar a independência da faculdade de juízo reflexivo (Gosto) no trato com a aparência ou natureza estética, como representação dos objetos pelo sujeito. Isto é, no fato de que, diz Kant, "[...] os objetos de conhecimento empírico são [...] determinados de muitos modos, fora daquela condição de tempo formal, ou, tanto quanto é possível julgar a priori, [na qual tais objetos são] suscetíveis de ser determinados" (Kant (1995), 27; (1968), XXXVII). Assim, evidencia-se o sentido pelo qual a faculdade de ajuizamento estético (Gosto) formaliza a representação de objetos empíricos mediante uma reflexão sistemática e unificadora, considerando-os desde a perspectiva de uma atividade autônoma exercida e fundada pela faculdade reflexiva do sujeito.

191 Por meio de tendências (Triebfedern) encontradas na natureza o sujeito é motivado a produzir representações em conformidade a regras, mas a autonomia para conduzir tais tendências até um uso exclusivamente subjetivo e aplicá-las conforme metas estipuladas pelo sujeito, depende da constituição da faculdade de ajuizamento do sujeito, 
que o resultado das representações assente como pertencente ao sujeito e independente dos objetos. Do ponto de vista da faculdade de juízo reflexiva, a forma pura do espaço foi tematizada em termos que permitem considerá-la vinculada tanto à aparência lógica como à aparência estética. Todavia, desta maneira, a forma pura do espaço tem de permanecer livre da imposição de ser associada exclusivamente à aparência lógica. Com efeito, diz Kant,

“[...] na representação sensível das coisas fora de mim a qualidade do espaço, no qual nós as intuímos, é aquilo que é simplesmente subjetivo na minha representação das mesmas (pelo que permanece incerto o que elas possam ser como objetos em si), razão pela qual o objeto também é pensado simplesmente como fenômeno (Erscheinung)."192

Visto não ser possível atribuir o mesmo sentido de realidade (Realität) às representações vinculadas ao estatuto lógico do entendimento e às vinculadas ao estatuto puramente estético, neste último enquanto ponto de vista estético-reflexivo, não é despertado o interesse na realidade da coisa; antes, importa a capacidade de julgar e avaliar nossa representação em relação à sensação de prazer

isto é, do Gosto (Kant (1995), 16; (1968), XIV). Pois, segundo Kant, “[...] o prazer está [...] no juízo de gosto verdadeiramente dependente de uma representação empírica e não pode estar ligado a priori a nenhum conceito (não se pode determinar a priori que tipo de objeto será ou não conforme ao gosto; será necessário experimentá-lo); porém, ele [prazer] é o fundamento da determinação deste juízo somente pelo fato de estarmos conscientes de que assenta simplesmente na reflexão e nas condições universais, ainda que subjetivas, do seu acordo com o conhecimento dos objetos em geral, para os quais a forma do objeto é conforme a fins" (Kant (1995), 35; (1968), XLVII).

192 Kant (1995), 33; (1968), XVII. Pois, segundo Kant, “[...] a sensação (neste caso a externa) exprime precisamente o que é simplesmente subjetivo das nossas representações das coisas fora de nós, mas no fundo o material (das Materielle) (real) das mesmas (pelo que algo existente é dado), assim como o exprime a simples forma a priori da possibilidade da sua intuição; e não obstante a sensação é também utilizada para o conhecimento dos objetos fora de nós" (Kant (1995), 33; (1968), XLII). 
produzida intrinsecamente pela atividade representativa humana. Neste sentido corrobora-se o exposto por Kant, visto que aqui fica evidente, dirá Schiller, que “[...] a realidade (Realität) das coisas é obra das coisas; [mas] a aparência (Schein) das coisas é obra humana, e uma mente (Gemüt) que aprecia a aparência (Schein) já não se compraz com o que recebe (empfängt), mas com o que faz (tut)."193 Do ponto de vista do entendimento (Verstand), porque o objeto (Gegenstand) não deve estar desgarrado de seu lugar sistemático, é

193 Schiller (1995), 134; (2010), 108. É interessante observar que, tributário da faculdade das intuições (a imaginação), o elemento da re-presentação (Vorstellung), quando referido à faculdade do conhecimento teórico (Verstand), traz consigo um componente de segunda mão. Kant definiu a faculdade de imaginação (Einbildungskraft) na Crítica da Razão Pura como a faculdade "[...] de representar um objeto, mesmo sem a presença deste na intuição" (Kant (1997), 151; (1968), B 151). Como faculdade de tornar presente por uma segunda vez o que não está mais presente (imediatamente) à sensibilidade, a imaginação propicia considerar a re-presentação como pertencente ao elemento de uma relação 'pensada' pelo entendimento, na constituição das categorias puras do entendimento. A re-presentação enquanto uma 'relação' pensada está condicionada no entendimento a 'lançar' diante dele diferentes possibilidades conceituais por meio da atividade sintética do pensamento puro. E nisso a re-presentação, enquanto relação pensada, fica sendo a possibilidade de o entendimento pensar diferentes conceitos ou elementos como postos em relação entre si (constituídos) por ele próprio. Neste sentido, a re-presentação não saiu ainda de relação de mero jogo, de mero tornar presente pela segunda vez o que esteve originariamente presente. Neste re-presentar como mero lançar diante de si pelo entendimento, este lida consigo mesmo e seus próprios elementos, os conceitos, na designação de uma determinação possível através deles. Por outro lado, considerada a re-presentação do ponto de vista puramente estético, como mero aparecer (Schein), evidencia-se a re-presentação como não podendo residir exclusivamente em relação à faculdade do conhecimento determinado (entendimento) e interessar apenas a ele. Em conformidade a isso Schiller enfatiza na passagem citada que, anterior ao trato do entendimento com as re-presentações, subsiste do ponto de vista estético, no re-presentar, uma autonomia e um livre estabelecimento de relações postas entre as re-presentações pensadas, antes de ter de vir a considerá-las imediatamente colocadas na dependência da natureza e da determinação lógica dos conceitos para o conhecimento pelo entendimento. Nas palavras de Kant na terceira Crítica, esse sentido pode ser extraído pela passagem na qual ele expressa, dizendo que: “[...] se a questão é se algo é belo, não se quer saber se, para nós ou para quem quer que seja, importa algo a existência da coisa, ou sequer se pode importar, mas sim como a julgamos na mera consideração (intuição ou reflexão)" (Kant (1995), 49; (1968), 5). Ou ainda nas palavras de Schiller: “O homem está nas mãos da natureza, mas a vontade do homem está em suas próprias mãos" (Schiller (1991), 56; (2009), 105). E afirma ainda: “O que o homem faz é justamente não se bastar com o que dele a natureza fez, mas ser capaz de refazer regressivamente com a razão os passos que ela antecipou nele, de transformar a obra de privação em obra de sua livre escolha e de elevar a necessidade física à necessidade moral" (Schiller (1995), 27; (2010), 11). 
pensada a noção de fenômeno (Erscheinung) de modo intrínseco e estrutural como trazendo em si o componente lógico da faculdade do entendimento e, neste sentido, ela também se faz presente na Crítica da Faculdade do Juizo. Porém, do lado da pura "representação" do ponto de vista estético, como aparecer (Schein) produzido pelo sujeito, toda a consideração da coisa como tendo um correspondente existindo exclusivamente fora do sujeito, à qual cabe atribuir objetividade, deve ser relativizada e dispensada. Isto é, do ponto de vista estético, as coisas têm de ser mantidas desde um ângulo meramente contingente e subjetivo. Isto permite conservar um sentido inequívoco à expressão do mero aparecer (Schein) como atendendo a um tipo específico de autonomia, aquela conferida ao sujeito exclusivamente pelo Gosto como faculdade de ajuizamento estético. Adiante será exposto de que modo a exclusiva ênfase na dimensão estética permite desenvolver o componente contemplativo e formador do Gosto, como faculdade reflexiva do sujeito na avaliação das formas do objeto.

\section{Faculdade reflexiva estética e alcance formador do Gosto}

Schiller acompanhou a coerência da distinção entre fenômeno (Erscheinung), aparecer (Schein) e coisa em si (Dinge an Sich) trazida pela Crítica da Razão Pura, e acrescentou, em conformidade com ela, um direcionamento: na medida em que o mero aparecer (Schein) não pode deixar de ter referência ao sujeito, pelo fato de o aparecer (Schein) ter sido produzido como representação (Vorstellung) pelas faculdades do sujeito ${ }^{194}$, tal aparecer tem de ser compreendido desde

194 Na equivocada relação estabelecida pelo dogmatismo (Berkeley) e ceticismo (Descartes), o passo em falso havia sido o de procurou admitir, para estofo de fundação do aparecer (Schein) produzido pela faculdade do sujeito, algo fora desta faculdade e para além da possível vinculação do aparecer como representação a uma faculdade própria, e não separada, do sujeito. No acompanhamento da crítica a esse equivocado 
a perspectiva sistemática, numa exigência mediante a qual a compreensão da natureza fica ao mesmo tempo implicada de um ponto de vista harmônico: graças ao Gosto surge a conexão sistemática da razão com os conceitos pensados desde a dimensão estética da aparência (Schein), reiterando a avaliação das formas do objeto como fundada no componente contemplativo e formador do Gosto. Com efeito, Kant tematizou inicialmente o aspecto estético da representação (Vorstellung), como devendo ser submetido ao estatuto transcendental da razão. Kant explicitou na terceira Crítica o estatuto da representação puramente estética, cuja demonstração dependia da fundação da faculdade transcendental do juízo reflexivo. Ao mostrar na Crítica da Faculdade do Juízo que a faculdade de juízo reflexiva é um "[...] termo médio entre o entendimento e a razão [...]" acerca da qual,

“[...] se tem razões para supor, segundo a analogia [às legislações puras do entendimento e da razão prática], que também poderia precisamente conter em si a priori, se bem que não uma legislação própria, todavia um princípio próprio para procurar leis [...]. “195

Kant acabou assegurando haver, todavia, diz ele, um "[...] abismo intransponível entre o domínio do conceito da natureza, enquanto sensível, e o do conceito de liberdade, como supra-sensível [...]"196. E, apesar da impossibilidade de se conhecer o conceito do fundamento

modo de vinculação, Schiller torna possível compreender o simples aparecer (Schein) como constituído por nossas faculdades. Em contraste com as abordagens dogmática e cética, tal representação é vista a partir das intenções de nossas faculdades, regidas pela faculdade de juízo reflexiva estética, na esteira do demonstrado pela Crítica da Faculdade do Juizo de Kant. Em tal abordagem Schiller reorienta a noção do simples aparecer (Schein) para a dimensão puramente estética e demonstra, do ângulo estético, a autonomia do Gosto como faculdade que desenvolve certas tarefas e tem metas a cumprir.

195 Kant (1995), 21; (1968), XXI.

196 Kant (1995), 20; (1968), XIX. Ainda Kant (1995), 39; (1968), LIII-LIV. 
da unidade do supra-sensível, justamente tal fundamento é que torna possível, complementa Kant, "[...] a passagem da maneira de pensar segundo os princípios de um [domínio] para a maneira de pensar segundo os princípios de outro [...]", 197 fazendo com que o domínio da liberdade exerça influência sobre o domínio da natureza, uma vez que do ponto de vista reflexivo-sistemático, o conceito de liberdade (moral) deve "[...] tornar efetivo no mundo dos sentidos o fim colocado pelas suas leis e a natureza, em consequência, tem que ser pensada de tal modo que a finalidade da sua forma concorde pelo menos com a possibilidade dos fins que nela atuam segundo leis da liberdade." 198 Portanto, através disso é facultada "[...] a passagem da maneira de pensar segundo os princípios de um [domínio: o teórico] para a maneira de pensar segundo os princípios de outro [o prático]"199.

$\mathrm{Na}$ carta inicialmente mencionada ao príncipe de Augustenburg (de 13 de julho 1793), ciente de ser não apenas possível, mas doravante necessário haver uma "[...] influência da cultura estética sobre a cultura moral [...]"200, Schiller observa ter identificado também que as "[...] leis da arte não estão fundadas nas formas mutáveis de um gosto de época contingente [...], mas sim no necessário e no eterno da natureza humana, nas leis originárias do espírito." 201 Segundo ele, faltava até agora "[...] um código de leis [...], e provê-la disso é um dos mais difíceis problemas que a razão filosofante pode se propor" ${ }^{202}$. Após

197 Kant (1995), 20; (1968), XX.

198 Kant (1995), 20; (1968), XIX-XX.

199 Kant (1995), 20; (1968), XX. Kant não omite do escopo da faculdade reflexiva do juízo estético a tarefa de tornar possível considerar a ideia de que nas belas formas naturais a própria natureza é que vem ao nosso encontro, manifestando sua solicitude e disposição (forma estética) para se harmonizar com nossos propósitos espirituais (formas morais). Kant define Gosto como "[...] a faculdade de ajuizamento de um objeto ou de um modo de representação mediante uma complacência [...] independente de todo interesse. O objeto de uma tal complacência se chama belo" (Kant (1995), 55; (1968), 16).

${ }^{2005}$ chiller (2009), 84, (2010), 144.

201 Schiller (2009), 82; (2010), 143.

202 Schiller (2009), 83; (2010), 143-4. 
haver tematizado o desempenho do conceito de graça em conjunção com o conceito de dignidade no opúsculo Sobre Graça e Dignidade, um problema que faltava resolver e impedia a elaboração de tal código de leis da formação estética e ao mesmo tempo moral do homem, era: porque à razão filosófica se tornara difícil realizar esse código de leis? Dirigindo-se ao príncipe, Schiller aprofunda sua interrogação e pergunta: "[...] o que pode ser mais difícil do que [...] unir a liberdade com a necessidade?" 203 Subjacente às noções de graça e dignidade, Schiller traz a dificuldade apontada já por Kant, inerente à tarefa de unir a liberdade com a necessidade, como na impossibilidade de haver uma ponte entre razão prática e razão teórica. Na terceira Crítica, como foi visto, Kant municiou seu argumento com o pressuposto segundo o qual, diz ele,

“[...] a natureza [...] tem que ser pensada de tal modo que a finalidade da sua forma concorde pelo menos com a possibilidade dos fins que nela atuam segundo leis da liberdade." 204

Apesar da impossibilidade da passagem do domínio teórico ao domínio prático, o caminho inverso é possível já que, embora “[...] os fundamentos de determinação da causalidade segundo o conceito de liberdade [...] não se possam testemunhar na natureza, e o sensível não possa determinar o suprassensível no sujeito [...]"205, no que se refere às consequências do conceito de liberdade, pelo fato de que o seu "[...] efeito deve acontecer no mundo de acordo com estas suas leis formais [...]"206, ocorre a passagem do domínio prático ao teórico. Por esse meio se reitera que a questão mais difícil não é a da união da liberdade e da necessidade, mas a da apresentação de um modo inequívoco de

\footnotetext{
203 Schiller (2009), 83; (2010), 144.

${ }^{204}$ Kant (1995), 20; (1968), XX (itálicos meus).

205 Kant (1995), 39; (1968), LIV.

206 Kant (1995), 39; (1968), LIV.
} 
demonstrar essa união, cuja plasticidade atenda a contento tanto a esfera teórica quanto a esfera prática da razão. Ao tematizar na Crítica da Razão Pura (1787) o arbítrio humano com base na diferença entre natura ectypa e natura archetypa 207 , Kant cunhou a distinção entre arbitrium liberum, arbitrium sensitivum, e arbitrium brutum: o primeiro determinado independentemente dos impulsos sensíveis (portanto, pela razão prática); o segundo patologicamente afetado pelos impulsos sensíveis; e o terceiro patologicamente necessitado e unicamente animal ${ }^{208}$. Todavia, diante da perspectiva schilleriana, que considera a própria natureza como vindo ao nosso encontro mediante suas belas formas (formas estéticas) a fim de se harmonizar com nossos propósitos espirituais (formas morais), parece insuficiente a necessidade de considerar sumariamente esgotada a classificação do arbítrio humano nos moldes kantianos. Isto porque, segundo Schiller, mediante a faculdade de ajuizamento estética (como faculdade ajuizante da comunicabilidade universal) é posta em xeque a ideia de que "[...] as paixões sensíveis [têm] o poder de oprimir positivamente a liberdade da mente [...]"209, visto que, completa ele, “[...] os sentidos só podem representar um poder contra o homem quando o espírito abdica livremente de provar-se como poder [...]" e, neste caso, "[...] seria desconhecer a natureza do espírito [...]" 210 o ato de conceder que as forças da razão fossem ou pudessem ser oprimidas.

Assim como Kant instituíra o homem como cidadão de dois mundos mediante a explicitação da razão prática (liberdade) como distinta da razão teórica (natureza), mediante o Gosto Schiller instituiu a beleza

“[...] como cidadã de dois mundos, pertencendo ao primeiro por nascimento e ao segundo por adoção [...] [já que] ela

\footnotetext{
${ }^{207}$ Kant (1997), 463 e 637; (1968), B 562 e B 830.

208 Kant (1997), 462; (1968), B 562.

209 Schiller (1995), 101; (2010), 75.

210 Schiller (1995), 101; (2010), 76.
} 
recebe sua existência na natureza sensível e obtém seu direito de cidadania no mundo da razão." 211

Aqui há uma função específica ao conceito da beleza: esta permite ao homem "[...] uma passagem da sensação ao pensamento [...]"212 sem que por isso deva ser entendido, diz Schiller, "[...] como se o belo preenchesse o abismo que separa a sensação / do pensamento, a passividade / da ação"213. O fato é que, completa ele,

“[...] este abismo é infinito, e [...] é eternamente impossível que surja algo universal / do individual, que surja o necessário / do contingente [...] sem interferência de uma faculdade nova e autônoma." 214

Não se trata aqui de que a natureza, considerada pelo entendimento, e a liberdade, considerada pela razão, recebam um tratamento incisivo a partir de uma faculdade nova, que as modifica ou adultera intrinsecamente nos seus domínios. Em vez disso, trata-se de que a partir do Gosto (faculdade de ajuizar a aparência livre ou a liberdade na aparência) ambas - natureza e liberdade - são vistas ao mesmo tempo do ponto de vista de seus limites, subjacente aos quais é posta em movimento uma nova atividade (nova faculdade) para mostrar que elas (natureza e liberdade) se conciliam no pensamento, ainda que a manifestação de tal ação imediata de conciliação se dê através da aparência (Schein) ou se manifeste passando pelos sentidos. Segundo Schiller, são nestes termos que "[...] a beleza pode tornar-se um meio de levar o homem da matéria à forma, das sensações a leis, de uma

\footnotetext{
211 Schiller (2008), 16-7; (2010), 80.

212 Schiller (1995), 100; (2010), 75.

213 Schiller (1995), 100; (2010), 75.

214 Schiller (1995), 100; (2010), 75.
} 
existência limitada à [existência] absoluta, apenas por proporcionar às faculdades do pensamento liberdade de se exteriorizarem segundo suas leis próprias - e não por ajudar no pensar (o que contém uma contradição manifesta) [...]"215, isto devido ao fato de que "[...] a autonomia com que o pensamento age exclui [já] toda influência estranha"216.

Para além da razão teórica (entendimento) e da razão prática é concedida, portanto, uma atividade às demais faculdades do pensamento: às faculdades de ajuizamento reflexivo e da imaginação pura (Einbildungskraft). A noção de aparência livre ou manifestação da liberdade no fenômeno, previamente desenvolvida na fase de correspondência com Körner, reaparece aqui visando agora se adequar ao cumprimento de uma função aplicativa, de que, à base da atividade teórica e prática da razão, desenvolve-se uma atividade reflexiva sobre o aparecer (Schein) do ponto de vista exclusivamente estético (faculdade de ajuizamento reflexivo). Daí que, em vez de ser o entendimento (Verstand) a faculdade encarregada a dar conta do que aparece à sensibilidade, isso cabe agora à faculdade da razão (Vernunft), em consonância com a natureza, já que o material sensível (a matéria) é considerado a partir de uma forma que apenas a razão (Vernunft) sabe dar e fornecer. Nesse caso a matéria (da sensibilidade) está para a razão, e não mais para o entendimento. À base disto se pode identificar, do ponto de vista ainda da razão prática, aqueles afetos cuja função não tem em vista desempenhar uma atividade a ser determinada pela faculdade da razão prática, já que são visados e vistos desde uma exposição ou manifestação exclusivamente estética.

A crítica de Schiller ao caráter pontual do rigorismo moral kantiano surge em Sobre Graça e Dignidade de modo contundente: afinal, para ser fiel acompanhante e seguidor da lei moral, não faria sentido indagar pelo ponto de vista da necessidade mais atual e urgente - face à qual

215 Schiller (1995), 100; (2010), 75.

216 Schiller (1995), 100; (2010), 75. 
aparecem contrapostas as dimensões humanas do ser selvagem (que tudo concede à sensibilidade) e do ser bárbaro (que tudo concede à razão ${ }^{217}$-, conforme o código de leis da formação estética e moral do homem, de um locus autêntico do apriorismo estético explicitado (na tematização da função do conceito de beleza, etc.), como devendo subjazer (este locus) de modo equidistante de ambas as condições extremas da humanidade? Ou nas palavras de Schiller, expressas em Sobre Graça e Dignidade, na qual ele indaga: só “[...] porque muitas vezes inclinações muito impuras usurpam o nome da virtude $[. . .]^{\prime \prime}$ se tornaria por isso suspeito "[...] o afeto desinteressado no peito mais nobre"? ${ }^{218}$ Ciente dos exageros cometidos pela concessão ao elemento puramente estético, atestado no dizer que só porque o homem de moral frouxa concede uma lassidão à manifestação da liberdade moral, inquire Schiller, devia por isso ser atribuída uma rigidez à lei da razão, mediante a qual a própria manifestação da liberdade moral se transforma numa "[...] espécie mais louvável de servidão"?219 Mas em tal caso, comenta ele,

“[...] terá o homem verdadeiramente ético uma opção mais livre (entre o respeito (auto-atenção) e o desprezo de si mesmo) que a opção do escravo entre o contentamento e a dor? [Pois] onde existirá menos coerção: aí para a vontade pura (respeito) ou aqui para a vontade corrompida (desprezo de si)?"220

217 Segundo Schiller, o sentido moral exige sem cessar "a expressão da humanidade", mas a condição do bárbaro comete transgressão por exigir abruptamente a saída da sensibilidade, ferindo nisso a expressão da humanidade. Por sua vez, pelo fato de o sentido estético não se satisfazer com a mera matéria, mas buscar "[...] na forma um contentamento livre [...]", complementa, ele "[...] se afastará, enojado, de uma [...] visão na qual apenas o desejo pode encontrar sua satisfação [...]", enquanto expressão reduzida à condição selvagem (animalidade), que nesta transgressão fere a dignidade (Schiller (2008), 36; (2010), 104).

218 Schiller (2008), 40; (2010), 109.

219 Schiller (2008), 40; (2010), 109.

220 Schiller (2008), 40; (2010), 109. 
O fato é que, complementa Schiller, a humanidade não tem de ser humilhada "[...] pela forma imperativa da moral [...]"221 e nem o "[...] documento mais sublime da sua grandeza [...]"222 deve ser o testemunho da sua fragilidade. Isso vinha sendo conduzido assim pelo rigorismo da teoria kantiana, que se mostrava refratária ao flanco aberto no intervalo entre o agir moral incondicionado e o agir condicionado pela natureza. A fim de não conferir, nem direta nem indiretamente, uma identificação da proposta kantiana com os extremos da condição humana (a do ser selvagem e a do ser bárbaro), Schiller apresenta o Gosto como a faculdade autônoma que deve exercer uma atividade sobre a passividade conservada pela cisão entre natureza (entendimento) e liberdade (razão prática), cisão entendida ao mesmo tempo como interrupção da atividade e das tarefas, tão logo a razão teórica (entendimento) e a razão prática tenham dado conta de suas aplicações conceituas nos respectivos domínios de legislação.

Por meio da atuação do Gosto, Schiller compreende a tarefa de efetivar uma humanidade mais sublime, ou seja, que o homem deva ser considerado por primeiro como uma totalidade ética. Isto porque, diz ele, o homem não está destinado a executar "[...] ações éticas singulares $[\ldots]$ "223, mas antes a ser um "[...] ser ético [...]"224, e apenas "[...] sua capacidade de agir como um ser ético dá ao homem direito (Anspruch) à liberdade." 225 . Graça (belo) e Dignidade (moral) têm de ser concebidas como atuando em parceria, única forma pela qual se alcança uma expressão harmônica da aparência (Schein), que caracteriza cada uma delas, seja voltada à manifestação da lei moral, seja voltada ao belo226.

\footnotetext{
221 Schiller (2008), 40-1; (2010), 109.

222 Schiller (2008), 41; (2010), 109.

223 Schiller (2008), 38; (2010), 106.

224 Schiller (2008), 38; (2010), 106.

225 Schiller (2009), 77; (2009), 139.

226 No dizer de Schiller, “[...] sentimo-nos livres na presença da beleza, porque os impulsos sensíveis harmonizam com a lei da razão; [e] sentimo-nos livres na presença
} 
Isso de modo algum significa proceder a uma interferência de uma pela outra no domínio contíguo. Segundo Schiller, tanto graça quanto dignidade tem um domínio próprio, sendo forçoso não confundir a especificidade de cada uma delas. Pois, por um lado, diz ele,

“[...] a capacidade de sentir o sublime é uma das mais esplêndidas faculdades humanas, que tanto merece o nosso respeito devido à sua origem na autônoma faculdade da razão e da vontade, como merece o mais completo desenvolvimento mercê da sua influência sobre o homem moral."227

Em vista disso, vê-se que sem o sublime "[...] o belo nos faria esquecer a nossa dignidade [...]"228 e na preguiça (indolência) de um prazer e de uma fruição continuada ocorreria que nós só “[...] causaríamos dano à robustez do caráter [...]"229. E, uma vez presos a essa "[...] forma casual da existência, perderíamos de vista a nossa inalterável missão e a nossa verdadeira prática" ${ }^{230}$. Contudo, se nos deixássemos pender puramente para o lado do empenho em satisfazer a nossa missão espiritual, então aí viríamos a perder “[...] a nossa humanidade [...]", já que sem o belo "[...] haveria um litígio ininterrupto entre a nossa destinação natural e a destinação racional [...]"231, ou seja, com isso permaneceríamos "[...] para sempre estranhos nesta esfera de ação a nós designada, preparados a todo momento para

do sublime, porque os mesmos impulsos perdem toda a influência sobre a legislação, pois o que atua aqui é o espírito, e o faz como se não obedecesse a nenhuma outra lei que não as suas próprias" (Schiller (1991), 54; (2009), 103).

227 Schiller (1991), 68; (2009), 115-6.

228 Schiller (1991), 69; (2009), 116.

229 Schiller (1991), 69; (2009), 116.

230 Schiller (1991), 69; (2009), 116.

231 Schiller (1991), 69; (2009), 116. Contudo, Schiller concede que devido à constituição mesma da natureza, o Gosto é, "[...] entre todas as faculdades da alma, a última a receber o seu amadurecimento." Schiller (1991), 60; (2009), 108. 
deixarmos o mundo dos sentidos." 232 Em vista disso, diz ele, senão mediante um modo pelo qual a lei seja considerada "[...] compatível com o seu sentimento de liberdade [...]"233, como entender que a lei moral não deva tomar "[...] a aparência de uma lei estranha e positiva [...], difícil de ser atenuada [...]"?234

Pelo conceito de beleza é entrevisto e se obtém o modo de pensar a lei moral como compatível tanto com o sentimento de liberdade pois a beleza é "[...] obra da livre contemplação, e com ela penetramos no mundo das ideias, sem deixar o mundo sensível [...]"235, como ocorre no conhecimento da verdade -, quanto vista como cidadã de dois mundos, por adoção e por direito, uma vez que a beleza é "[...] forma, porque a contemplamos, mas é ao mesmo tempo vida, porque a sentimos. Numa palavra: é simultaneamente nosso estado e nossa ação" 236 . E, por ser “[...] os dois ao mesmo tempo [...]", ela é a prova decisiva "[...] de que a passividade não exclui a atividade, nem [que] a matéria exclui a forma, nem a limitação exclui a infinitude" 237.

232 Schiller (1991), 69; (2009), 116.

233 Schiller (2008), 41; (2010), 109.

234 Schiller (2008), 41; (2010), 109. Por sua vez, por meio das noções de destinação (totalidade ética) e afeto desinteressado pode-se contrastar o desenvolvimento de um caminho que contorna a condução da questão moral fundamental, como em Kant, ao domínio e à necessidade dos Postulados Práticos da razão, na Crítica da Razão Prática. Pois, colocada a postulação de uma harmonia (de natureza ou felicidade, e razão ou virtude) na ideia do Sumo Bem, assentada na noção de um dever ser, como dizia Hegel, se teria através disso "[...] uma saída muito fácil [...]" do problema, visto tal ideia (sumo Bem) se ater "[...] na separação do conceito e da realidade [...]", portanto contra a efetiva realização do Fim Último (letzter Zweck) como harmonia realizada entre ambas (Hegel (1995), 131-2). Comparada à exigência schilleriana de assentar do ponto de vista reflexivo a totalidade ética e o ser ético, o postulado de um Sumo Bem parece transcendente e por isso obsoleto diante das tarefas reflexivas que identificam o indivíduo de razão como imediatamente voltado ao conteúdo e à formação ética dos impulsos e dos afetos. Pois, como dirá Schiller: "O supremo ideal, pelo qual nos esforçamos, é o de permanecermos em boa relação com o mundo físico, guardião de nossa felicidade, sem por isso sermos obrigados a romper com o mundo moral, que determina a nossa dignidade" (Schiller (1991), 66; (2010), 113).

235 Schiller (1995), 131; (2010), 104.
236 Schiller (1995), 131; (2010), 105.
237 Schiller (1995), 131; (2010), 105. 
Assim se elucida que pela dependência física do homem não fica suprimida, de modo algum, a sua liberdade moral, e que se "[...] o homem não precisa fugir da matéria para afirmar-se como espírito [...]"238, é mais fácil compreender em que sentido o rigorismo moral kantiano, necessário mas também fruto circunstanciado de uma época, entende as inclinações (arbitrium sensitivum) do ponto de vista moral como exclusivamente "[...] em guerra com a lei da razão"239, em vez de também "[...] em acordo com essa lei" ${ }^{240}$. No primeiro caso a inclinação fora considerada uma companhia ambígua “[...] do sentimento ético e contentamento [...]"241; porém, na medida em que o preceito da inclinação não é o de alcançar " [...] virtudes [diferentes], mas a virtude é seu preceito [...]"242, a inclinação pode passar a ser entendida desde um terreno neutro.

Em carta ao príncipe (de 3 de dezembro 1793), Schiller enfatizou o tipo de conflito trazido pelo impulso sensível como sendo "[...] o mais perigoso inimigo interno da moralidade"243: este impulso está "[...] incessantemente ocupado em atrair a vontade em seu interesse $[\ldots]$ "244; porém, ao mesmo tempo a vontade "[...] está sob leis éticas e tem sobre si a obrigatoriedade de nunca se encontrar em contradições com as exigências da razão." 245 Daí que, face a esse "[...] mais forte adversário [...]"246 que o homem tem de combater no seu agir moral, pode-se tipificar uma escala das diferentes classes de ânimo (disposições de ânimo), conforme as quais se vê em operação um certo grau

\footnotetext{
238 Schiller (1995), 132; (2010), 106.

239 Schiller (2008), 37; (2010), 105.

240 Schiller (2008), 37; (2010), 105.

241 Schiller (2008), 37; (2010), 105.

242 Schiller (2008), 38; (2010), 106.

243 Schiller (2009), 139; (2010), 180.

244 Schiller (2009), 139; (2010), 180.

245 Schiller (2009), 139; (2010), 180.

246 Schiller (2009), 139; (2010), 180.
} 
prioritário do conflito entre a faculdade de apetição e a determinação ética. Ilustra Schiller essas classes, dizendo:

1) “Para o caso em que a apetição imediatamente dá a lei, existem os ânimos rudes, que agem meramente como apraz aos sentidos (falta a estes tanto formação moral como estética) $^{247}$;

2) "Para o caso em que a razão dá imediatamente a lei, existem os ânimos morais, que agem meramente pela consideração ao dever, já que só através desta [lei] eles já vencem a tentação (mas a estes falta formação estética) ${ }^{248}$; e

3) "Para o caso em que é exigido "decoro" e "moderação", pelo qual se ganha muito para a civilização e a eticidade há a formação estética, que mesmo não produzindo nenhuma virtude, enfraquece a sensibilidade, na medida em que a faculdade reflexiva estética (Gosto) faz coerção até um grau de domínio sobre a manifestação dos afetos, rompendo "[...] a cega violência dos mesmos (afetos) [...]", acabando por "[...] abrir espaço para a vontade se voltar para a virtude". Em tal caso, "onde falta a virtude, o Gosto a substitui, e onde a virtude está presente, o Gosto a facilita." 249

Na mesma medida em que tem de ser colocado limite aos ímpetos da natureza (já que mesmo "[...] na tormenta da sensação ouvimos a voz da razão" ${ }^{250}$ ), o Gosto é eleito na disposição de ânimo estética (refinada) como o primeiro combatente contra a rude natureza. Porém, o tipo de liberdade alcançada pela vontade não se constitui aqui como

\footnotetext{
247 Schiller (2009), 140; (2010), 180.

248 Schiller (2009), 140; (2010), 180-1.

249 Schiller (2009), 140; (2010), 181.

250 Schiller (2009), 140; (2010), 181.
} 
liberdade moral251, pois não se opera nenhuma ação ética mediante o Gosto: este apenas liberta o ânimo do jugo do instinto, conduzindo o último a sua própria prisão. Vê-se assim que, na escala apresentada das diferentes classes de submissão do ânimo de ser atraído à vontade em vista de um interesse, o Gosto rege o ânimo através de um atrativo do prazer, cuja fonte é a razão, e tal prazer será por isso nobre. Por isso o Gosto mostra toda a sua desenvoltura neste contexto: onde a razão está em perigo de ser derrotada pela eloquência forte da natureza, o Gosto será positivamente útil à verdadeira virtude, já que aqui o Gosto afina a sensibilidade “[...] em proveito do dever, e faz [...] que mesmo um grau menor de força de vontade moral esteja

251 Não se trata, diz Schiller, de imiscuir o gosto nas determinações morais da razão prática, mas antes de imiscuir o gosto "[...] nas operações da vontade" (Schiller (2009), 141; (2010), 182). Kant advertiu, na Introdução da Crítica da Faculdade do Juízo, que "[...] a vontade, como faculdade de apetição, é especificamente uma dentre muitas causas da natureza no mundo, a saber, aquela que atua segundo conceitos, e tudo o que é representado como possível (ou como necessário) mediante a vontade se chama prático-possível (ou prático-necessário)" (Kant (1995), 16; (1968), XII-III). Falta demonstrar, no início do desenvolvimento do domínio (Gebiet) da faculdade de juízo reflexivo, de que modo esta faculdade assenta na vontade, e não na natureza, ou seja, enquanto um "[...] termo médio entre o entendimento e a razão" (Kant (1995), 21; (1968), XXI), para fundamento da atividade reflexiva do juízo, no qual é pensada "[...] a vontade [que aqui] não se encontra simplesmente sob o conceito da natureza, mas sim sob o da liberdade, em relação ao qual os princípios da vontade se chamam leis [...]." Por isso, até que sejam suficientemente distinguidas as atividades das faculdades de entendimento (natureza) e da razão (liberdade), segundo Kant, tem de permanecer "indeterminado, no que respeita ao prático, se o conceito que dá a regra à causalidade da vontade é um conceito de natureza ou da liberdade" (Kant (1995), 16; (1968), XII-III). O princípio da finalidade da natureza (Zweckmässigkeit) constitui um princípio técnico como um princípio da natureza, pensado por leis e regras colocadas como condicionadas pelo conceito da liberdade. Para Kant, se entende deste modo que o "[...] nosso conceito de uma finalidade subjetiva da natureza, nas suas formas segundo leis empíricas, não seja de modo nenhum um conceito de objeto, mas sim um princípio da faculdade de juízo para arranjarmos conceitos nesta multiplicidade desmedida (para nos orientarmos nela)" (Kant (1995), 37; (1968), L), ou seja, o conceito de uma conformidade a fins (Zweckmässigkeit) da natureza "[...] não é nem um conceito de natureza, nem de liberdade, porque não acrescenta nada ao objeto (da natureza), mas representa somente a única forma segundo a qual temos que proceder na reflexão sobre os objetos da natureza com o objetivo de uma experiência exaustivamente interconectada, por conseguinte é um princípio subjetivo (máxima) da faculdade do juízo" (Kant (1995), 28; (1968), XXXIV). 
à altura do exercício da virtude." $252 \mathrm{E}$, ainda que sejam separados, com maior nitidez um do outro, o homem físico e o homem moral (ou as disposições de ânimo moral e sensitiva), o próprio conflito entre razão e sensibilidade propicia a sua unificação. Pois, diz Schiller, justamente desde a perspectiva deste conflito se torna visível de que modo o mundo moral determina a nossa dignidade: não através da busca pelo bem-estar físico (arbitrium sensitivum), nem pela simples concordância, a partir do belo, pois,

“É justamente com relação a tais órgãos que, onde o primeiro [homem físico] só sente as suas limitações, o outro faz a experiência de sua força e se sente infinitamente elevado precisamente por aquilo que esmaga o outro contra o solo." 253

Daí que, acrescenta ele, nós

“[...] só somos perfeitos cidadãos da natureza (ou somos um ser ético) quando o sublime se conjuga com o belo e a nossa receptividade relativamente a ambos teve igual formação $[\ldots] ", 254$

252 Schiller (2009), 145; (2010), 185. Em vista disso se permite concluir apenas que "[...] o gosto pode favorecer a moralidade da conduta [...], mas ele mesmo nunca pode produzir algo moral através de sua influência [...]" (Schiller (2009), 136-7; (2010), 177), uma vez que, completa Schiller, "[...] o ético jamais pode ter um outro fundamento que não ele mesmo [...]" (Schiller (2009), 137; (2010), 177), sendo que, por seu turno, "[...] o sublime nos obtém uma saída do mundo sensível, dentro do qual o belo gostaria de nos manter presos para sempre" (Schiller (1991), 58; (2009), 107). Por outro lado, evidencia-se que "[...] o gosto não pode causar nenhum prejuízo à verdadeira virtude" (Schiller (2009), 144; (2010), 185), enquanto as ações despertadas por um impulso natural e que provocam aqui seu primeiro estímulo regem "[...] muito mais ações indiferentes do que verdadeiramente morais" (Schiller (2009), 144; (2010), 185). O gosto só oferece "[...] ao ânimo uma adequada [conforme a fins] disposição para a virtude, pois afasta os movimentos da natureza que a impedem e desperta aqueles que lhe são favoráveis" (Schiller (2009), 144; (2010), 184).

253 Schiller (1991), 56; (2009), 105.

254 Schiller (1991), 69; (2009), 116. 
isto é, só aqui não somos "[...] seus escravos e nem perdemos os nossos direitos de cidadãos no mundo inteligível" 255 . Por sua vez, se o homem não fosse capaz de nenhuma outra cultura que não a do mundo físico, então teria de se conceder que "[...] a liberdade do homem estaria liquidada" 256 . Em vista disso, a aparência estética (ästhetischer Schein) nunca se tornará perigosa à verdade dos costumes, pois, individualmente dirigida a cada uma das faculdades, razão teórica e razão prática, que conservam um domínio e uma legislação específica, ela representa um caráter neutro e inócuo, já que "[...] a vontade tem uma conexão mais imediata com a faculdade da sensação do que com a dos conhecimentos [...]"257 e, também, visto que "[...] a natureza humana é um todo mais unido na efetividade do que é permitido ao filósofo [suspeitar] [...]" natureza esta que o filósofo "[...] só é capaz de dissociar, deixá-la parecer [...]"258.

A pressuposição de que o desenvolvimento de afetos alcance também, individual e diretamente, seja com o entendimento, seja com a razão, um aspecto desinteressado (neutro), não representa por sua vez que, na consideração conjunta de ambas as faculdades pelo Gosto, não se obtenha uma nova nuance para uma nova atividade e função a partir deles: mediante o Gosto, os afetos são úteis também para o desenvolvimento e enobrecimento dos sentimentos e para o refinamento da vontade e do pensamento. Neste contexto, Schiller estabelece o paralelo entre o papel desempenhado pelo Gosto e o representado pela Religião.

255 Schiller (1991), 69; (2009), 116. Em carta ao príncipe, diz Schiller: “[...] no mesmo momento em que a razão profere sua sentença, também a sensibilidade passará para o lado dela, e ele fará com inclinação o que sem esta terna receptividade para o belo teria de ter conseguido contra a inclinação" (Schiller (2009), 144; (2010), 184).

256 Schiller (1991), 51; (2009), 100.

257 Schiller (2008), 41; (2010), 87.

258 Schiller (2008), 41; (2010), 87. 
Foi visto como estabelecida mutuamente pela relação entre razão e sensibilidade uma sensibilidade esteticamente considerada, explicitada pela noção da Graça, e foi tematizada por esse meio a presença da natureza caracterizada na perspectiva conciliadora, repercutida enquanto aparência (representação e jogo, sem depender da existência da natureza, mas antes só da capacidade de ajuizamento), e dos elementos subordinados à razão (dignidade, conciliação a partir do conflito, destinação do ser humano como ser ético). Viu-se ainda que apesar do conflito, do abismo intransponível e da impossibilidade de uma ponte (fixada) entre os domínios teórico e prático, o Gosto fora apresentado como faculdade autônoma e com um código próprio de leis, em favor da ampliação na consideração da atividade das demais faculdades que, anteriormente, permaneceram passivas e reféns da atividade das faculdades teórica e prática da razão. Daí que o Gosto, na medida em que enfraquece a sensibilidade e faz coerção até dominar a manifestação dos afetos, através disso rompendo "[...] a cega violência dos mesmos (afetos) [...]" 259 e abrindo “[...] espaço para a vontade se voltar para a virtude $[\ldots]^{\prime 260}$, enquanto facilitador da virtude e também seu representante (mas não seu substituto), ainda produz isso: onde está ausente a virtude, o Gosto traz a sua capacidade enobrecedora e, devido à formação estética, ganha algo para a Eticidade e para a Civilização. Neste âmbito dá-se a paridade entre Gosto e Religião, assentada do mesmo modo que o Gosto, forma pela qual são expulsas do ânimo “[...] aquelas inclinações materiais e rudes apetites, que frequentemente se contrapõem tão tenaz e tempestuosamente ao exercício do bem [...]"261, motivo pelo qual o Gosto implantará em vez delas outras “[...] inclinações mais nobres e mais suaves [...]"262 referidas à ordem, harmonia

\footnotetext{
259 Schiller (2009), 140; (2010), 181.

260 Schiller (2009), 140; (2010), 181.

261 Schiller (2009), 141; (2010), 182.

262 Schiller (2009), 141; (2010), 182.
} 
e perfeição, ainda que não sejam virtudes. Por sua vez é reservada à Religião uma atuação nas situações em que o maior refinamento do Gosto "[...] não pode impedir o impulso sensível de insistir numa satisfação material [...]”263, ou seja, a “[...] Religião é para o homem sensível o que o Gosto é para o homem refinado; o Gosto é para a vida habitual o que a Religião é para os momentos extremos." 264 Schiller explica e exemplifica isso: na medida em que não somos deuses, “[...] temos de nos assegurar, quando não de preferência em ambos, em um destes dois apoios"265. Para a maior parte do povo, a sua Religião “[...] é o contrapeso de suas paixões, onde nenhuma resistência externa rompe o seu vigor"266. Daí que apenas como cristão (religioso) um homem comum proibirá a si mesmo muito do que ele teria se permitido como homem; e exclusivamente por isso as classes esteticamente mais refinadas se chamarão de civilizadas (gesittet), sem que ao mesmo tempo pudessem ser chamadas também de éticas (sittlich).

Na medida em que Religião e Gosto podem ser considerados como compartilhadores do "[...] mérito de servir de sucedâneo da verdadeira virtude e de assegurar a conformidade à lei das ações onde não se é de esperar - das convicções - a conformidade ao dever" 267 , por meio da Religião e da virtude estética (Gosto) é possível a nós nos prendermos “[...] nos intervalos livres [...] para que nossa paixão não se enfureça, nos períodos do seu domínio, contra a ordem do mundo [...]"268, no qual a Religião contribui com a tarefa de assegurar o respeito pelas normas morais.

263 Schiller (2009), 149; (2010), 188.

264 Schiller (2009), 151; (2010), 189. Como adiciona Schiller, “[...] se em nenhum caso o gosto prejudica a verdadeira moralidade, e em muitos, porém, é manifestamente útil, então $a$ circunstância de que ele é vantajoso no mais alto grau à legalidade de nossa conduta tem de receber um grande peso" (Schiller, (2009), 146; (2010), 185).

\footnotetext{
265 Schiller (2009), 151; (2010), 189.

266 Schiller (2009), 151; (2010), 189-90.

267 Schiller (2009), 148-9; (2010), 187.

268 Schiller (2009), 148; (2010), 187.
} 


\title{
III. Resposta a Kant: compatibilização do Gosto e da Moral
}

\author{
Kant imputara ser irrealizável, na recensão ao opúsculo Sobre \\ Graça e Dignidade em nota n'A Religião nos Limites da Simples Razão \\ $(1793)^{269}$, a proposta de Schiller de associar graça (elemento estético)
}

269 Kant (1992), 29-30, nota 6; (1968), 669. Kant diz: “[...] Confesso de bom grado que não posso associar graça alguma ao conceito de dever, justamente por mor da sua dignidade. Com efeito, tal conceito contém uma compulsão incondicionada, com a qual a graça se encontra em contradição direta" (Kant (1992), 29-30; (1968), 669). Ao imputar a Schiller uma vinculação indevida do elemento estético (graça) ao elemento moral (dignidade), em A Religião nos Limites da Simples Razão Kant fornece a ilustração disso pela menção dos dois tipos distintos de amor, representados miticamente, como objeção feita ao Sobre Graça e Dignidade de Schiller. Diz Kant: "[...] Se se intrometem no negócio da determinação do dever e para tal querem subministrar os motivos [...]" então "[...] as acompanhantes de Vênus Urânia são cortesãs no séquito de Vênus Díone" (Kant (1992), 29-30; (1968), 669). Pode-se cogitar como sendo o diálogo O Banquete, de Platão (a partir de 180 d), uma das possíveis fontes da qual Kant se serviu para extrair a distinção expressa no texto d'A Religião nos Limites da Simples Razão. No relato d'O Banquete, o personagem Pausânias apresenta duas noções distintas do amor (duas Afrodites): a Vênus Urânia, filha de Urano, referida ao amor espiritual e celestial; e a Vênus Pandêmia (a popular), filha de Zeus e de Díone, referida à forma mais jovem do amor. Uma vez que exige ser mais explicitado "o dom que a um e a outro [destes deuses] coube" (Platão (1972), 21), Pausânias discorre e nisto confirma: "[...] o amor de Afrodite Pandêmia é realmente popular e faz o que lhe ocorre; é a ele que os homens vulgares amam [...], [e] o que neles amam é mais o corpo que a alma [...]. Trata-se com efeito do amor proveniente da deusa que é mais jovem que a outra, e que em sua geração participa da fêmea e do macho" (Platão, 1972, 21-2). Por sua vez, continua dizendo Pausânias, "o outro [amor] (...) é o da Urânia, que primeiramente não participa da fêmea, mas só do macho e [...] é a mais velha, isenta de violência. [...]; daí então é que se voltam ao que é másculo os inspirados neste amor, afeiçoando-se ao que é de natureza mais forte e que tem mais inteligência" (Platão (1972), 22). Adiante concluirá então o personagem Erixímaco, dizendo: "[...] aos homens moderados, e para que mais moderados se tornem os que ainda não sejam, deve-se aquiescer e conservar o seu amor, que é o belo, o celestial, o Amor da musa Urânia [...] "(Platão (1972), 27), enquanto sói ao outro ser fonte dos sentimentos pessoais e das paixões. Nestes termos, de que modo pode se considerar com tendo inserido sentido no veto kantiano de associar dignidade e graça a ilustração dos dois tipos de amor, Vênus Urânia e a Vênus Díone, trazida em A Religião nos Limites da Simples Razão? Não parece evidente que pela figura da Vênus Díone alcança Kant o domínio de expressão da graça (Unmuth), como propôs Schiller em Sobre Graça e Dignidade, na figura da deusa da beleza cujo cinturão transmite graça àquele que o porta. Por seu turno, permanece aí evidenciada a Vênus Urânia como representante do caráter puro do amor e da dignidade. Na Fundamentação da Metafísica dos Costumes (Kant (1997), 30; (1968), BA 13-14) Kant realizou a distinção entre amor prático (praktische Liebe), motivador de ações segundo a lei moral (vontade racional e autônoma), e amor patológico (pathologische Liebe) e condicional, motivador de ações baseadas em inclinações sensíveis (vontade sensivelmente afetada e heterônoma). As- 
e dignidade (o conceito de dever moral). Entretanto, a partir de nossa exposição feita sobre as questões em seu vínculo sistemático, foi visto que Schiller não quis que o conceito de dignidade (sublimidade da lei moral) devesse ser encontrado na graça (Gosto) e nem vice-versa. Ele é taxativo ao afirmar em Do Sublime que se a dignidade contém uma compulsão incondicionada, também o gosto traz em si uma compulsão incondicionada, porém desde um domínio omniabrangente e puramente estético. Por sua vez, referindo-se ao espaço reservado à faculdade estética (Gosto) como domínio ao qual cabe ao homem desempenhar um novo papel em sociedade, ele contemporiza alegando reconhecer o quão importante é a dignidade no conceito do dever e da lei moral, afirmando comungar ele próprio da importância da moralidade (lei moral) na atualidade. Porém, o que ele coloca em xeque são apenas os efeitos imediatos ao todo da sociedade, do privilégio concedido exclusivamente ao exercício da lei moral, cercada pelas duas condições pouco suscetíveis de compreender o ideal da humanidade (a que concede demais aos elementos da sensibilidade, e a do que o faz inteiramente só ao elemento puro da lei), como atitudes imediatas tanto mais invariáveis quanto por elas os homens mostram que não estão preparados por suas faculdades ao jogo e à vida em sociedade em conformidade com o ideal de humanidade.

Neste sentido surge a dimensão aplicativa do Gosto, desenvolvida como nuance complementar ao momento da fundação da faculdade

\footnotetext{
sim, se por um lado faz sentido entender a figura de Vênus Urânia como referida ao amor prático que conserva a dignidade, por outro faltam elementos para subordinar à Deusa Díone (consorte de Zeus) algo além da mera participação no amor patológico e condicionado. Neste sentido fica faltando a Kant a descoberta do verdadeiro sentido e da correta nuance trazida no mito da deusa da beleza, expresso por Schiller em Sobre Graça e Dignidade, que jamais promoveu a que "as acompanhantes da Vênus Urânia" se misturassem com as companhias da Vênus Díone. De modo mais direto, Schiller parece ter resolvido isso na Educação Estética do Homem (Carta VI, 1995, 42), ao atribuir um papel exclusivo à Vênus Urânia (o amor espiritual), e outro à Vênus Citeréia (o amor carnal), vetando qualquer tipo de comércio ou aproximação entre elas, conservando-as por isso como domínios distintos e para sempre separados. Confirma-se por isso a Schiller como um intelectual autônomo, cuja teoria não pode ser reduzida à teoria elaborada por Kant.
} 
reflexiva: ao seu dizer, o Gosto, na medida em que vem suavizar e reparar a violência feita à sensibilidade, desde o domínio puro (rigorista) da razão, apresenta-se como o meio de promover a atividade das faculdades superiores do espírito, facilitando o domínio da razão sobre a sensibilidade, pelo seu fundamento posto à humanidade. E porque daí se extrai um proveito para a Eticidade, enquanto tanto o Gosto quanto a Religião ganham a faculdade sensível, já que mediante a sensibilidade é enobrecida a Eticidade, pelo Gosto, como "[...] faculdade de ajuizar a comunicabilidade universal de um sentimento [...]"270, é promovida a influência recíproca na reflexão do ser natural e da inteligência, por meio da qual se unificam as faculdades superiores e inferiores. Em vista disso, a situação só será difícil, diz ele,

“[...] onde nenhuma cultura estética abriu o sentido interno e aquietou o externo, e as sensações mais nobres do entendimento e do coração ainda não limitaram as necessidades comuns dos sentidos." 271

Aqui, o modo de aplicar o juízo estético surge conforme a noção de natureza pressuposta na tematização kantiana na Crítica da Faculdade do Juízo, de uma natureza que vem ao nosso encontro. Noutras palavras: só em virtude de que “[...] a própria natureza já apresenta um grande número de objetos em que se poderia exercitar a sensibilidade pelo belo e pelo sublime [...]"272 é que então, relativo ao Gosto como atividade dirigida aos afetos e à sensibilidade, "[...] não se pode permanecer neutro sem se tornar culpado da mais punível indiferença diante do que tem de ser o mais sagrado para o homem

\footnotetext{
270 Schiller (2004), 38; (1963), 69.

271 Schiller (2009), 149; (2010), 188.

272 Schiller (1991), 69; (2009), 116.
} 
[...]"273, ou seja, tem de se tomar ciência desta nova modalidade de destinação humana, mediante a apuração do conjunto dos afetos, consoante uma concepção orgânica e sistemática ${ }^{274}$, que encontra e, igualmente, legitima a evidência de afetos desinteressados, pela uso e manutenção mesma da atividade do Gosto como faculdade no interstício das faculdades de conhecimento teórico e prático, e não por uma investigação especulativa.

Ciente da ambiguidade que à época rodeava a expressão "estética", em nota à Carta XX, diz Schiller:

"Para leitores que não se encontrem bem ao corrente do significado puro desta palavra, tão erroneamente usada por ignorância, as considerações seguintes podem servir de explicação. Tudo o que seja de algum modo passível de se manifestar como fenômeno pode ser pensado sob quatro aspectos. Uma coisa pode se relacionar diretamente com o nosso estado sensível (a nossa existência e bem-estar); isto é o seu caráter físico. Ou pode se relacionar com o entendimento, e proporcionar-nos um conhecimento; isto é o seu caráter lógico. Ou pode se relacionar com a nossa vontade e ser considerada como objeto de escolha para um ser racional; isto é o seu

\footnotetext{
273 Schiller (2009), 71; (2010), 135.

274 Segundo Schiller, “[...] dado que a cultura do belo não poderia de modo algum contribuir para nos tornar melhor intencionados, ela nos torna ao menos hábeis para agir mesmo sem uma convicção verdadeiramente ética, como uma convicção ética o teria exigido" (Schiller (2009), 146; (2010), 186). E continua: "Pois bem, ambas as ordens do mundo, a física, onde forças governam, e a moral, onde leis governam, estão [...] tão exatamente calculadas uma para a outra e tão intimamente tecidas entre si, que ações que, segundo sua forma, são moralmente [adequadas] conforme a fins, ao mesmo tempo encerram, pelo seu conteúdo, uma [adequação] conforme a fins física; e assim como todo o edifício da natureza parece existir apenas para tornar possível o mais alto de todos os fins, que é o bem, assim o bem se deixa usar de novo como um meio para manter de pé o edifício da natureza. A ordem da natureza é tornada, pois, dependente da eticidade das nossas convicções, e não podemos violar o mundo moral sem ao mesmo tempo causar uma perturbação no mundo físico" (Schiller (2009), 146; (2010), 186).
} 
caráter moral. $\mathrm{Ou}$, finalmente, pode se relacionar com o todo das nossas diversas faculdades, sem ser um objeto determinado para uma só delas, e isto é o seu caráter estético." ${ }^{275}$

O quadro de engajamento no qual a faculdade estética adquire a função aplicada prática (mas não moral), visando à cultura e à formação dos indivíduos, dos povos e da humanidade, e servindo de anteparo e baliza para encarar o que parece ser "[...] o sinal para a grande transformação e uma união dos ânimos [...]"276, acentua a visão de conjunto da sociedade da época em que muito fora feito "pelo esclarecimento do entendimento, [...] [sendo que agora] a necessidade mais urgente da nossa época parece-me ser o enobrecimento dos sentimentos e a purificação da vontade" 277 .

A questão da consideração do Gosto a partir do caráter da sua aplicação parece apontar, no dizer de Schiller, ao fato de que "[...] o grande destino da humanidade está posto em questão" 278 . E, ciente dos acontecimentos recentes da Revolução Francesa e execução do Rei Luís XVI (em 21 de janeiro de 1973), a função pedagógica e extensiva do Gosto como faculdade autônoma e autorreflexiva reside em fornecer as condições sensíveis (factuais e estéticas) para constituir os meios de uma resposta ao mesmo tempo mais fundamental aos acontecimentos da época, cuja esperança, depositada só no que a razão prática podia realizar ou dela era dado esperar, havia caído por terra. Diante do curso dos acontecimentos políticos Schiller considera ceticamente o quadro das tarefas intelectuais a serem desincumbidas pela época. Face à cultura teórica herdada do Esclarecimento (Aufklärung), cuja influência fora tão pouco enobre-

\footnotetext{
275 Schiller (1995), 107nota; (2010), 81-2, Fussnote.

276 Schiller (2009), 74; (2010), 137.

277 Schiller (1995), 79; (2010), 33.

278 Schiller (2009), 71; (2010), 135.
} 
cedora, diz ele, “[...] sobre as convicções, que antes ajudam apenas a fazer da corrupção um sistema e torná-la irremediável [...]"279, pode se entender a sua resposta mais ampliada à relação mantida entre graça e dignidade como resposta à recensão de Kant, isto é, menos desacreditando da faculdade moral que a temperando através da inserção e ampliação do conjunto de atividades das faculdades transcendentais do sujeito, mediante o Gosto, Schiller declara:

"Queria despedir-me eternamente das musas e dedicar toda minha atividade [...] à monarquia da razão, [mas isso somente] se fosse verdadeiro o fato de que a legislação política fora confinada à razão, de que o homem fora respeitado e tratado como um fim em si mesmo, de que a lei fora elevada ao trono e a verdadeira liberdade tornada em fundamento do edifício do Estado." 280

Porém, na medida em que isso (que o homem fora tratado como um fim em si, que a verdadeira liberdade se tornou fundamento) não se dá regularmente ou apenas se dá como caso extraordinário, justo este fato, diz Schiller,

“[...] é o que ouso pôr em dúvida. [Portanto] sim, estou tão longe de crer no início de uma regeneração no âmbito político, que os acontecimentos da época antes [pelo contrário] me tiram por séculos todas as esperanças disso." 281

279 Schiller (2009), 76; (2010), 139.

280 Schiller (2009), 73; (2010), 137.

281 Schiller (2009), 73; (2010), 137. Noutras palavras: “[...] se jamais cabe esperar da natureza humana - enquanto ela permaneça natureza humana - que aja, sem interrupção e recaída, uniforme e persistentemente como pura natureza espiritual, que nunca viole a ordem ética, bem como nunca se encontre em contradição com as prescrições da razão - se em toda convicção temos de confessar, tanto da necessidade como da possibilidade da virtude pura, quão contingente é o seu exercício efetivo e quão pouco 
Na tarefa de adequar a faculdade estética aplicada a apurar a transformação do homem no reconhecimento de haver nele a índole de afetos desinteressados, vinculados à sua destinação (alcançar o ideal da humanidade), Schiller propôs menos o descrédito na faculdade da razão prática que a transformação harmônica dos afetos e da sensibilidade. Menos que promover uma atração entre os elementos morais e os elementos estéticos, como associação entre o fundamento da lei moral (dignidade), conservada de modo intransigente pela razão pura, e o fundamento estético (graça) da faculdade de julgar, cuja atividade reflexiva é transitiva entre as faculdades teórica e prática da razão, Schiller reitera que os elementos morais e os estéticos, no fundo, não se rejeitam mutuamente ${ }^{282}$. Assim como se pressupõe o sentimento de respeito à lei como móbil da ação moral, também se tem de pressupor um afeto desinteressado como móbil da reflexão estética ${ }^{283}$, que atua em conjunto com a perspectiva moral, mas sem ofuscá-la nem substituir a sua perspectiva necessariamente intransigente.

Exclusivamente porque o aspecto corretivo da lei moral parece limitado em seu alcance a pouquíssimos casos é que, pela admissão do Gosto, pode ser beneficiada a necessária modificação íntima na determinação dos móbeis à ação. Se a razão prática (moralidade), devido ao rigorismo adequadamente atinente a sua fundamentação, não

estamos autorizados a edificar sobre a inexpugnabilidade dos nossos melhores princípios [...] - se nos recordamos de tudo isto, então a mais injuriosa temeridade seria deixar o melhor do mundo depender desta causalidade de nossa virtude. Disto resulta para nós antes uma obrigatoriedade de satisfazer ao menos a ordem física do mundo através do conteúdo de nossas ações - ao menos como instrumentos mais perfeitos, de pagar ao fim da natureza o que nós, como pessoas imperfeitas, permanecemos devendo à razão, para não ficarmos reprovados com desonra em ambas as ordens do mundo ao mesmo tempo" (Schiller (2009), 147; (2010), 186).

282 A aproximação entre os elementos estéticos e morais fora desenvolvida por Kant, ainda que noutros termos, no parágrafo $\$ 59$ da Crítica da Faculdade do Juízo (Kant (1995), 195-199; (1968), 254-260), ao tematizar a ideia do belo como símbolo do moralmente-bom (a ideia da beleza como símbolo da moralidade).

283 Do ponto de vista do entrosamento das esferas ética e estética pode por isso servir de mote: conhecer o móbil (prático-moral) e sentir o afeto (estético), como elementos sistematicamente complementares. 
dá conta disso, o Gosto tem condições de converter harmonicamente os afetos e modificar apropriadamente a sensibilidade, visto que se obteria uma formação cultural precária se restasse admitir o caráter ético como tendo de, por fim, se afirmar unicamente "[...] com o sacrifício do natural [...]"284. Diante do privilégio da época esclarecida (ilustrada), desenvolvida à sombra da primazia das razões teórica e prática, a denúncia da inoperância e alienação das demais faculdades do sujeito apontou a que só pela concepção conjunta das faculdades humanas, do ponto de vista sistemático, podia ser cumprida a tarefa incumbida ao Gosto, de colocar todas as faculdades em uma ativa harmonia, como expressão apropriada do ideal da humanidade. Por esse meio, outras importantes faculdades transcendentais do sujeito são mantidas ativas e sistematicamente vinculadas às suas tarefas próprias, fazendo com que se conduzam ao máximo em seu próprio exercício, conservando latente seu caráter orgânico sem que nenhuma (nem entendimento, nem razão prática, nem imaginação e nem sensibilidade) saia prejudicada.

A adequação das representações, também ao critério de uma estética do aparecer (Schein), permite compreendê-las desde a atividade conjunta da faculdade dos conceitos (entendimento) e da faculdade das intuições (imaginação), do ponto de vista de uma atividade não-determinante. Enquanto atividade em uma relação de mero jogo, ela pode interessar à faculdade da razão associada ao Gosto, já que mediante isso contempla todas as faculdades (atividades) do sujeito. E se era complementar uma aplicação ainda ao momento de fundação da representação, na função concreta a ser desempenhada pelos conceitos estéticos, isso se deve a que a condição de se pensar os objetos é fornecida pelo seu lugar sistemático. Por isso, a crítica à primazia de fazer oscilar a inteira atividade do pensamento apenas sob os domínios do entendimento e da razão prática dependia da

284 Schiller (1995), 32; (2009), 16. 
demonstração do momento da aplicação como complementar ao da fundação. Seria bom poder crer como sendo também conforme a este sentido que Kant estabeleceu a segurança do princípio da realidade e idealidade das formas espácio-temporais da sensibilidade humana, na Crítica da Razão Pura, na qual apresentou a Estética Transcendental como sendo "[...] tão certa e tão indiscutível quanto se pode exigir de uma teoria que deva servir de organon" 285.

\section{IV . Conclusão}

Uma vez mantidos os momentos de fundação e aplicação estruturalmente associados pode-se entender a concepção harmônica entre natureza e razão na exigência schilleriana. Devido à prioridade do ponto de vista do Gosto a aparência (Schein) pode ser entendida desde uma perspectiva autônoma, fundada também no estatuto transcendental do método de pensar. Enquanto explicitação da vinculação harmônica entre matéria (sensibilidade) e razão, essa nova relação posta em claro por Schiller decerto excede a indeterminação ínsita na proposta de Kant de tematizar as faculdades do sujeito como meras condições de possibilidade de conhecer os objetos, num uso apenas canônico. Todavia, ainda assim, à revelia das pretensões de Kant, ela evidencia-se como legítima.

\section{Referências Bibliográficas}

ALlisON, Henry. F. (1992): El Idealismo Transcendental de Kant: Una Interpretación y Defensa. Trad. Dulce M. G. Castro. Barcelona: Anthropos.

AllisON, H. (1998): "O quid facti e o quid juris na Crítica de Kant do Gosto". In Studia Kantiana 1 (1), pp. 83-99.

285 Kant (1997), 81; (1968), B 63. 
HABERMAS, Jürgen (2000): O Discurso Filosófico da Modernidade. Trad. Luiz S. Répa; Rodnei Nascimento. São Paulo: Martins Fontes.

HAMM, Christian (2009): “Experiência Estética em Kant e Schiller". In: Werle, Marco A.; Galé, Pedro F. (org.). Arte e Filosofia no Idealismo alemão. São Paulo: Barcarolla.

HEGEL, Georg. F.(2002): Enciclopédia das Ciências Filosóficas em compêndio. Trad. Paulo Meneses. São Paulo: Ed. Loyola, vol. I.

KANT, Immanuel (1968): Werkausgabe: in zwölf Bänden. Hrsg. von Wilhelm Weischedel. Frankfurt am Main: Suhrkamp.

KANT, Immanuel (1997): Crítica da Razão Pura. Trad. Manoela P. dos Santos; Alexandre F. Morujão. Lisboa: Calouste Gulbenkian.

KANT, Immanuel (1995): Crítica da Faculdade do Juizo. Trad. Valério Rohden; António Marques. $2^{a}$ ed. Rio de Janeiro: Forense Universitária.

KANT, Immanuel (1992): Fundamentação da Metafísica dos Costumes. Trad. Paulo Quintela. Lisboa: Ed. Setenta.

KANT, Immanuel (1992): A Religião nos Limites da Simples Razão (1793). Trad. Artur Morão. Lisboa: Ed. Setenta.

LEIBNIZ, Gottfried W. (2004): Novos Ensaios sobre o Entendimento Humano. Trad. Adelino Cardoso, $2^{\mathrm{a}}$ ed. Lisboa: Ed. Colibri.

Platão, (1972): O Banquete. In: __: Diálogos. Trad. José Cavalcante de Souza. São Paulo: Abril S. A., $1^{\text {a }}$ ed. (Col. Os Pensadores).

SANTOS, Leonel R. dos (2006): Hans Vaihinger: o Kantismo como um Ficcionalismo? In:___ (org.): Kant: Posteridade e Actualidade. Lisboa: CFUL, pp. 515-536.

ROSSET, Clément (1988): O Real e seu Duplo: Ensaio sobre a Ilusão. Trad. José T. Brum. Porto Alegre: L\&PM.

SCHILLER, Friedrich (1963): Fragmente aus Schillers Aesthetischen Vorlesungen vom Winterhalbjahr 1792-93. In:___: Schillers Werke Nationalausgabe. Hrsg. H. Koopmann u. Benno von Wiese. Bd. 21.Weimar: Hermann Böhlaus Nachfolger.

SCHILLER, Friedrich (2010): Kallias oder über die Schönheit. Herausg. Klaus L. Berghahn. Stuttgart: Reclam.

SCHILlER, Friedrich (2010): Über Anmut und Würde. Herausg. Klaus L. Berghahn. Stuttgart: Reclam.

SCHILLER, Friedrich (2010): Über die ästhetische Erziehung des Menschen. Herausg. Klaus L. Berghahn. Stuttgart: Reclam.

SCHILLER, Friedrich (2010): Briefen an den Prinzen Friedrich Christian von Schleswig-Holstein-Sonderburg-Augustenburg (Februar bis Dezember 1793). In:_: Über die ästhetische Erziehung des Menschen. Herausg. Klaus L. Berghahn. Stuttgart: Reclam.

SCHILLER, Friedrich (2009): Ueber das Erhabene. In: _.: Vom Pathetischen und Erhabenen. Schriften zur Dramatheorie. Herausg. Klaus L. Berghahn. Stuttgart: Reclam.

SCHILLER, Friedrich (2002): Kallias ou sobre a beleza. A correspondência entre Schiller e Körner entre janeiro e fevereiro 1793. Trad. Ricardo Barbosa. Rio de Janeiro: Jorge Zahar.

SCHILLER, Friedrich (2008): Sobre Graça e Dignidade (1793). Trad. Ana Resende. Porto Alegre: Movimento. 
SCHILLER, Friedrich (1995): A Educação Estética do Homem (1795). Trad. Roberto Schwarz; Márcio Suzuki. $3^{\mathrm{a}}$ ed. São Paulo: Iluminuras.

SCHILLER, Friedrich (2004): Fragmento das Preleções sobre Estética do semestre de inverno 1792-3. Trad. Ricardo Barbosa. Belo Horizonte: Ed. UFMG.

SCHILLER, Friedrich (1991): Do Sublime (1793). In: Schiller: Teoria da Tragédia. Trad. Anatol Rosenfeld. São Paulo: EPU.

SCHILleR, Friedrich (2009): Cartas ao Príncipe de Augustenburg (fev.-dez. 1793). In: Schiller: Cultura Estética e Liberdade. Trad. Ricardo Barbosa. São Paulo: Hedra.

VAIHINGER, Hans (2011): A Filosofia do Como Se: Sistema das Ficções Teóricas, Práticas e Religiosas da Humanidade, na Base de um Positivismo Idealista. Trad. Johannes Kretschmer. Chapecó: Argos. 
